\title{
Compression Behaviour of Reconstituted Soils at High Initial Water
}

\section{Contents}

\author{
Zhen-Shun Hong ${ }^{1}$, Jie Yin ${ }^{2}$, Yu-Jun Cui ${ }^{3}$
}

1: Professor, Ph.D, Institute of Geotechnical Engineering, Southeast University, Nanjing 210096, P. R. China.

2: Doctoral Student, Geotechnical Institute, Hohai University, Nanjing 210098, P. R. China. (currently Ph.D, Faculty of Science, Jiangsu University, Zhenjiang 212013, P. R. China.)

3: Professor, Ph.D, Ecole des Ponts - ParisTech, UR Navier/CERMES, 6 et 8, avenue Blaise Pascal, Cité Descartes, Champs-sur-Marne, 77455 Marne La Vallée cedex 2, France

\section{Corresponding Author:}

Zhen-Shun Hong, Ph.D, Professor

Institute of Geotechnical Engineering

Southeast University

Nanjing 210096

P. R. China

Tel: +86-25-83792220

Fax: +86-25-83795086

Email: zshong@seu.edu.cn 


\begin{abstract}
Oedometer tests starting from a very small effective vertical stress of $0.5 \mathrm{kPa}$ were performed on three reconstituted clays with different liquid limits. The soils were prepared at various initial water contents, ranging from 0.7 to 2.0 times their corresponding liquid limits. It is observed that the $e-\log \sigma_{v}{ }^{\prime}$ compression curves show an inverse "S" shape due to suction pressure resisting deformation, similar to that of soft natural clays caused by consolidation yield stress. The suction pressure $\sigma_{s}$ ' of the reconstituted clays can be correlated with the ratio of initial void ratio to void ratio at liquid limit $e_{0} / e_{L}$. The suction pressure curve (SPC) defined by a unique relationship between suction pressure $\sigma_{s}{ }^{\prime}$ and the normalised void ratio at suction pressure $e_{s} / e_{L}$ is also proposed to distinguish between the pre-suction and the post-suction states. In addition, Burland's concept of intrinsic compression line (ICL) is adopted for correlating the compression curves of various reconstituted clays at high initial water contents. It has been found that the void index is a powerful parameter for normalising the compression curves in the post-suction state. Nevertheless, it seems that Burland's ICL slightly underestimates the void index at the low stresses considered in this study. An extended intrinsic compression line (EICL) is then derived in order to better fit the data for stresses lower than $25 \mathrm{kPa}$.
\end{abstract}

KEYWORDS: reconstituted clays; compressibility; initial water content; liquid limit; soil properties; suction pressure

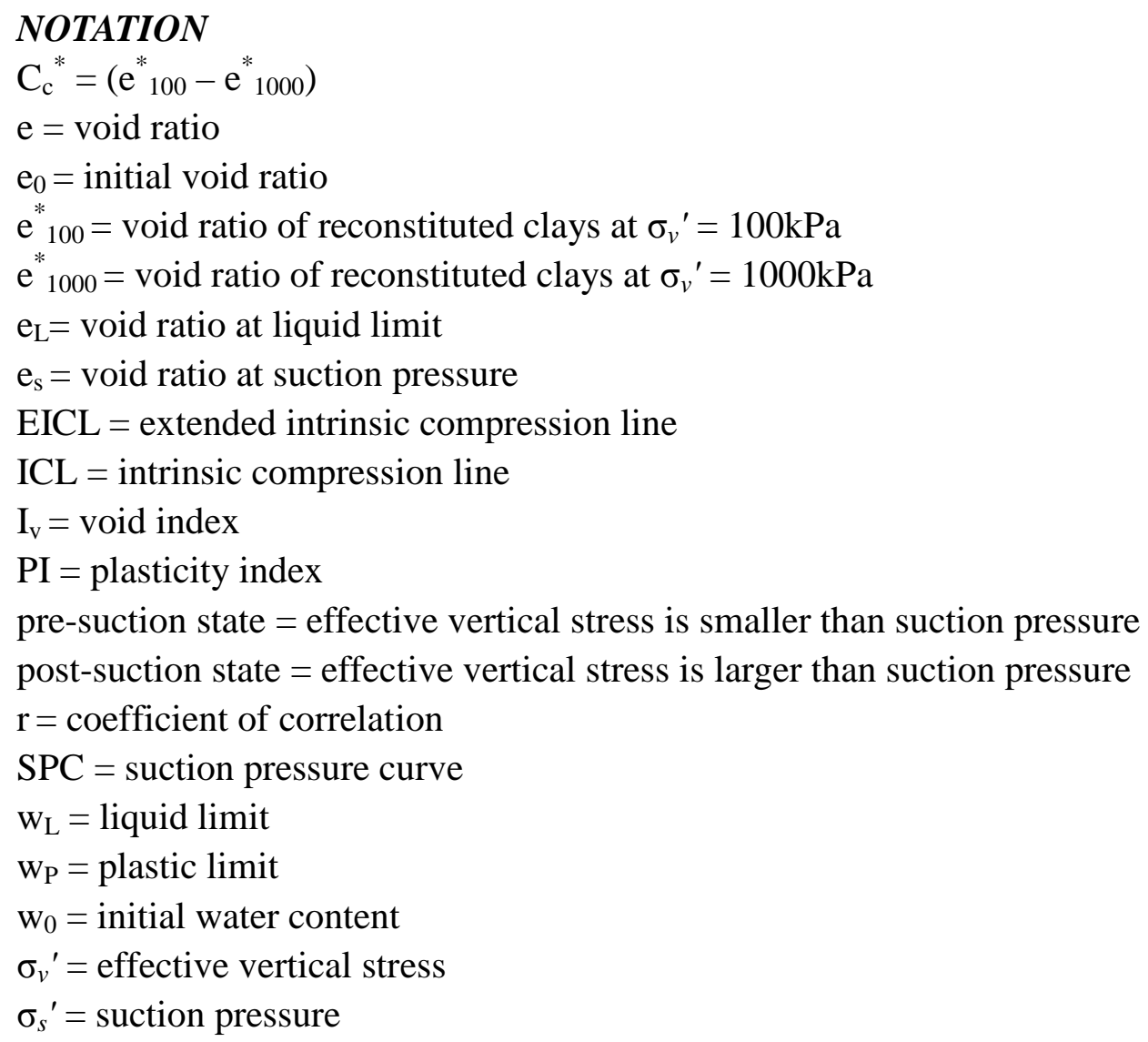




\section{INTRODUCTION}

Many studies have been carried out to assess the in-situ mechanical behaviour of natural sedimentary soils (e.g. Skempton and Northey, 1953; Houston and Mitchell, 1969; Nagaraj and Srinivasa Murthy, 1986; Hight et al., 1987; Burland, 1990; Leroueil and Vaughan, 1990; Cotecchia and Chandler, 1997; Hong and Tsuchida 1999; Chandler, 2000; Cotecchia and Chandler, 2000). It has been widely recognised that natural sedimentary soils generally behave differently from reconstituted soils due to the effect of soil structure (e.g. Leroueil et al., 1979; Leroueil et al., 1985; Locat and Lefebvre, 1986; Schmertmann, 1991). The most notable concept allowing quantitative evaluation of the difference in compression behaviour between natural sedimentary soils and reconstituted soils is the intrinsic compression line (ICL) proposed by Burland (1990) with introducing the normalised void index, $I_{v}$. Based on this intrinsic concept, Cotecchia \& Chandler (2000) and Chandler (2000) made an important contribution by developing a sensitivity framework for comparison of the mechanical behaviour between natural sedimentary and reconstituted clays.

As noted by Burland (1990), the intrinsic compression curve was established based on reconstituted soils at an initial water content of 1.0 and 1.5 times the liquid limits (mostly 1.25 times). For natural deposits, however, their initial water contents are not always around 1.25 times the liquid limits; values larger than 1.5 times the liquid limits can be obtained (Buchan and Smith, 1999). Skempton (1970) reported that the mean water contents in the top $250 \mathrm{~mm}$ of sea bed are about 1.5 times their liquid limits, and the clays deposited in tidal flats have initial water contents close to their liquid limits. Tsuchida and Gomyo (1995) reported that water contents of most natural undisturbed samples obtained directly by divers in about the top $200 \mathrm{~mm}$ layer of sea bed in Tokyo Bay, Hiroshima Bay, Matsushima Bay and Biwa Lake are within the range of 1.5-2.0 times their liquid limits. The results from oedometer tests reported by Certo and Lutenegger (2004) also indicated that the initial water contents of samples may significantly affect the intrinsic parameters defined by Burland (1990).

Several studies have showed that fine-grained soils at their liquid limit state have measurable shear strength of about 1.5 - $2.0 \mathrm{kPa}$ (e.g. Wroth and Wood, 1978; Whyte, 1982; Leroueil et al., 1983; Locat and Demers, 1988). Russel and Mickle (1970) studied a wide range of clays and observed that the liquid limit corresponds to the water content at a moisture tension of about $6 \mathrm{kPa}$. These results are in agreement with the liquid limit definition by Grim (1962, in Russel and Mickle 1970): “...The liquid limit is a measure of the water which can be held with any substantial rigidity, and does not separate the particles, but approaches the point where there is substantially no bonding force between them...". It is thus clear that the fine-grained soils are not at fully virgin state at their liquid limits. Subsequently, the soils may present an apparent "preconsolidation pressure" upon compression. Note that the increase of apparent preconsolidation pressure due to suction or moisture tension increase is commonly observed on most unsaturated fine-grained soils (e.g. Alonso et al., 1987, Alonso et al., 1990, Cui and Delage, 1996). Obviously, this apparent 
"preconsolidation pressure", called suction pressure in Hong (2007), would have significant effect on Burland's intrinsic compression line. In this paper, the term 'suction pressure' will be used in describing this phenomenon.

The objective of this study is to investigate the compression behaviour of reconstituted clays using oedometer tests. Emphasis is put on the following two points that, to the authors' knowledge, have not been dealt with by former studies: starting from a very low effective vertical stress of $0.5 \mathrm{kPa}$, and using specimens with a wider range of initial water contents from 0.7 to 2.0 times the liquid limits. This work is complementary to the intrinsic compression line concept proposed by Burland (1990). The following main questions will be addressed: (1) how does the suction pressure affect the compressibility of reconstituted clays? (2) how does the suction pressure depend on the reconstituted soils nature? (3) is it possible to extend Burland's intrinsic concept to a wider range of initial water contents?

\section{MATERIALS AND METHODS}

The three clays (designated as Lianyungang clay, Baimahu clay, and Kemen clay, respectively) used in this study were taken from Lianyungang city of Jiangsu province, Huaian city of Jiangsu province, and Fuzhou city of Fujian province in China respectively, as shown in Figure 1. Lianyungang clay and Kemen clay deposit around Yellow Sea and East China Sea, respectively. Baimahu clay corresponds to a fluvial deposit. The undisturbed samples of Lianyungang clay were obtained from the depth of about $2.5 \mathrm{~m}$ below ground surface using a polyvinyl chloride tube of $300 \mathrm{~mm}$ in diameter and $300 \mathrm{~mm}$ in height. The in-situ water content of Lianyungang clay is $66 \%$. The samples of Baimahu clay were taken from a site reclaimed by the deposition of soils dredged from the bed layer of the Grand Canal. The water content of Baimahu clay is very high, about 3 times the liquid limit. The samples of Kemen clay were taken from the land reclaimed by the deposition of soils dredged from the sea bed for harbour construction. The in-situ water content of Kemen clay is $60 \%$.

The basic physical properties of these soils are shown in Table 1. The liquid limits were measured using Casagrande Method (BS1377: Part 2: 1990: 4.3); the plastic limit tests were also carried out on the same samples used for the liquid limit tests in accordance with BS1377: Part2: 1990: 5.3, as suggested by Head (1992). Figure 2 shows the plasticity chart for the investigated soils. It can be seen that all lie slightly above the A-line defined by $P I=0.73\left(w_{L}-20\right)$, where $P I$ is the plasticity index, and $w_{L}$ represents the liquid limit.

As noted by Head (1992), the initial effective vertical stress for oedometer tests should be appropriate for the type of soil to prevent soil squeezing out through the clearance gap between the ring and the upper porous disc. The standard oedometer apparatus is generally designed for an initial pressure greater than $6 \mathrm{kPa}$ or $10 \mathrm{kPa}$. Soils which are at an initial water content greater than the liquid limit are often not stiff enough to support such an initial effective vertical stress, and consequently soil squeezing occurs. For this reason, in this study, the standard oedometer apparatus was modified so as to be suitable for soil specimens at high initial water contents, greater than their liquid limits. The modified oedometer apparatus is equipped with a light 
loading cap and two weight hanger systems. A schematic diagramme of the modified oedometer test rig is shown in Figure 3. The first hanger is under the centre point of the consolidation cell, while the second one is the same as for a standard oedometer test rig. When the required vertical stress is less than $12.5 \mathrm{kPa}$, the second weight hanger used in the standard oedometer test rig is removed. The load is applied by gradually adding weights to the first weight hanger. The first vertical stress applied is $0.5 \mathrm{kPa}$. The vertical stress is then gradually increased to $12.5 \mathrm{kPa}$, in the following steps: $0.5 \mathrm{kPa}, 1.5 \mathrm{kPa}, 2.5 \mathrm{kPa}, 3.5 \mathrm{kPa}, 5.5 \mathrm{kPa}, 7.5 \mathrm{kPa}, 9.5 \mathrm{kPa}, 12.5 \mathrm{kPa}$ for both Lianyungang clay and Baimahu clay, and $0.5 \mathrm{kPa}, 1.5 \mathrm{kPa}, 3.5 \mathrm{kPa}, 6.5 \mathrm{kPa}, 12.5 \mathrm{kPa}$ for Kemen clay. The effect of loading rate is not considered here. When the $12.5 \mathrm{kPa}$ stress step is completed, the consolidation stresses of $25 \mathrm{kPa}, 50 \mathrm{kPa}, 100 \mathrm{kPa}$, $200 \mathrm{kPa}, 400 \mathrm{kPa}, 800 \mathrm{kPa}$ and $1600 \mathrm{kPa}$ are subsequently applied by adding slotted weights to the second weight hanger in the same fashion as in a standard oedometer test. The soil specimen has a diameter of $61.8 \mathrm{~mm}$ (area of $30 \mathrm{~cm}^{2}$ ) and a nominal height of $20 \mathrm{~mm}$. The duration of every load increment is about 24 hours.

The initial water contents, $w_{0}$, of the clay specimens were adjusted within the range of 0.7-2.0 times their liquid limits, as shown in Table 2. In total 42 tests were performed on the three reconstituted clays. It should be mentioned that the specimens were adjusted by adding and mixing with distilled water. When the targeted value of the initial water content (designed as $0.7,0.8,0.9,1.0,1.1,1.2,1.3,1.4,1.5,1.6,1.7$, 1.8, 1.9 and 2.0 times their liquid limits, respectively) is greater than the in-situ content of sampled samples, distilled water was added and mixed to make the specimen approach the targeted value of the initial water content. When the targeted value of the initial content is less than the in-situ content, the specimen was air-dried to be somewhat smaller than the targeted value. Then, the required quantity of distilled water is added and mixed to approach the targeted value of the initial water content. After adjusting the initial water content, the specimen was carefully put into the oedometer ring by controlling the mass of the specimen. With the measured initial water content shown in Table 2, the mass of a specimen can be calculated in a fully saturated condition. The measured values of mass put into the oedometer ring for all specimens were almost identical to the calculated values with an error being less than $2 \%$.

\section{COMPRESSION CURVES}

Figure 4 presents the compression curves in terms of changes in void ratio versus effective vertical stress in a semi-logarithmic plot $\left(e-\log \sigma_{v}\right)$ for the three reconstituted clays: Lianyungang clay, Baimahu clay and Kemen clay, in (a) to (c) respectively. The symbols used in the figures denote the various initial water contents. It is interesting to note that all the compression curves show an inverse " $\mathrm{S}$ " shape except for the sample of Kemen clay with an initial water content of $122 \%$. It should be pointed out that the inverse "S" shape has seldom been reported for $e-\log \sigma_{v}$ " compression curves of reconstituted soils with high initial water contents.

Burland (1990) reported that the $e-\log \sigma_{v}$ compression curves of reconstituted clays at an initial water content of 1.0-1.5 times the liquid limit are in a shape slightly 
concave upwards for the stress greater than $10 \mathrm{kPa}$. Hong (2007) showed similar results for reconstituted Ariake clays. The notable difference in oedometer tests between Burland's and this study lies in the initial effective vertical stress. For relatively high stresses, when the effective vertical stress is greater than the stress corresponding to the inflection point of the $e-\log \sigma_{v}$ compression curves, i.e. the suction pressure as discussed previously, the compression curves shown in Figure 4 is indeed slightly concave upwards, consistent with the results reported by Burland (1990).

On the other hand, it has been well documented that the $e-\log \sigma_{v}$ compression curves of soft natural clays generally show an inverse "S" shape (e.g. Butterfield, 1979; Pelletier et al., 1979; Holtz et al., 1986; Hight et al., 1992; Hong and Onitsuka, 1998). The consolidation yield stress developed by the soil structure during depositional and post-depositional processes is considered to be responsible for the small compressibility when the effective vertical stress is lower than the consolidation yield stress (i.e. the pre-yield state). The compressibility dramatically increases from the pre-yield state to the post-yield state (i.e. the effective vertical stress is greater than the consolidation yield stress) (e.g. Butterfield, 1979; Pelletier et al., 1979; Holtz et al., 1986; Burland, 1990; Hight, et al., 1992).

The similarity of compression curves between reconstituted clays and natural soils indicates that there should be a particular stress responsible for the inverse " $\mathrm{S}$ " shape of $e-\log \sigma_{v}{ }^{\prime}$ compression curves of reconstituted clays, similar to the consolidation yield stress for natural soils. This particular stress is the above-mentioned suction pressure. Hong (2007) showed that there is a unique relationship between the ratio of initial void ratio $e_{0}$ to void ratio at liquid limit $e_{L}$ and the suction pressure $\sigma_{s}{ }^{\prime}$ for various reconstituted clays. In other words, the initial water content of a given reconstituted clay must correspond to a suction pressure. It is the suction pressure that resists the loads resulting in low compressibility in the range of low stresses. This is similar to the consolidation behaviour of natural soils when the applied stress is lower than the consolidation yield stress. Hence, the suction pressure of reconstituted clays can be determined in the same fashion as determining the consolidation yield stress for natural sedimentary soils.

For soft natural soils, it is well known that it is often ambiguous to determine the consolidation yield stress with the Casagrande method due to the inverse " $S$ " shape (e.g. Butterfield, 1979; Onitsuka et al., 1995). Butterfield (1979) firstly proposed the bilogarithmic method to interpret the oedometer test data of undisturbed samples for natural soils. The $e-\log \sigma_{v}$ ' compression curves with an inverse " $\mathrm{S}$ " shape can be well represented by two straight lines in the plot of $\log (1+e)$ or $\ln (1+e)$ against $\log \sigma_{v}{ }^{\prime}$ or $\ln \sigma_{v}{ }^{\prime}$. The effective vertical stress corresponding to the intersection point of the two straight lines is the consolidation yield stress. Several researchers (e.g. Onitsuka et al., 1995; Sridharan and Prakash, 1996; Hong and Onitsuka, 1998; Hong, 2007) verified the validity of the bilogarithmic method for undisturbed samples of natural soils. They showed that the oedometer test data of reconstituted clays can be also plotted by a straight line in the bilogarithmic graph, as long as the applied vertical stress is larger than the suction pressure or pre-consolidated stress. Hence, in the same way as 
interpreting the test data of natural soils, the oedometer test data of reconstituted clays with an inverse " $S$ " shape can be represented by two straight lines in the bilogarithmic graph.

The oedometer test data in Figure 4 are replotted in the graph of $\ln (1+e)$ against

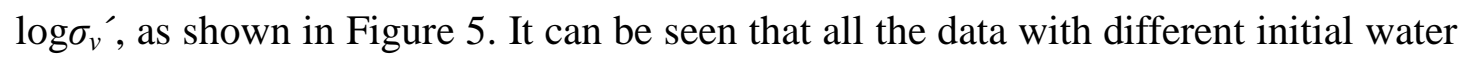
contents can be well represented by two straight lines in the bilogarithmic $\ln (1+e)$ $\log \sigma_{v}{ }^{\prime}$ graph, except for the sample of Kemen clay at an initial water content of $122 \%$ which can be almost represented by a straight line. The stress at the intersection point of the two straight lines is the suction pressure $\sigma_{\mathrm{s}}{ }^{\prime}$. The left straight line refers to the pre-suction state line when the effective vertical stress is lower than the suction pressure, while the right straight line refers to the post-suction state line when the effective vertical stress is larger than the suction pressure.

\section{SUCTION PRESSURE CURVE}

The results of suction pressure measured by the two straight lines for the investigated clays at different initial water contents are shown in Figure 6. It can be seen that the suction pressure $\sigma_{s}{ }^{\prime}$ decreases with an increase in initial water content for a given clay. Under the same initial water content, the value of suction pressure decreases in the order of Baimahu clay, Lianyungang clay and Kemen clay, the same order of decreasing liquid limits.

Hong (2007) showed that the void ratio at liquid limit $e_{L}$ can be used as a useful index for normalising the relationships between initial void ratio $e_{0}$ and suction pressure $\sigma_{s}{ }^{\prime}$ for various reconstituted clays. Figure 7 presents the relationship between the measured suction pressure $\sigma_{s}{ }^{\prime}$ and the normalised initial void ratio $e_{0} / e_{L}$ for all the studied reconstituted clays. Interestingly, a unique relationship between $\sigma_{s}{ }^{\prime}$ and $e_{0} / e_{L}$ is obtained, within a quite large range of both initial water contents (43\%-180\%) and liquid limits $(61 \%-91 \%)$. Note that the initial water contents are 0.7-2.0 times the liquid limits. A regression analysis gives the following simple equation with a correlation coefficient $r$ of 0.96 :

$$
\sigma_{\mathrm{s}}{ }^{\prime}(\mathrm{kPa})=5.66 /\left(\mathrm{e}_{0} / \mathrm{e}_{\mathrm{L}}\right)^{2}
$$

The above equation gives the value of suction pressure for various reconstituted soils at their liquid limits as $5.7 \mathrm{kPa}$, quite close to the value of $6.0 \mathrm{kPa}$ reported by Russel \& Mickle (1970) and Mitchell (1993).

Hong (2007) has proposed, in the absence of the pre-suction oedometer test data, a method of determining the suction pressures $\sigma_{s}{ }^{\prime}$ by extrapolating the post-suction oedometer test curve to the initial void ratio $e_{0}$ in the bilogarithmic $\ln (1+e)-\log \sigma_{v}{ }^{\prime}$ plot. The following normalised equation was given by Hong (2007) based on the oedometer test data of Ariake clays at various initial water content in the range of 1.0-1.4 times the liquid limits.

$$
\mathrm{e}_{0} / \mathrm{e}_{\mathrm{L}}=\left(2.14 / \sigma_{\mathrm{s}}\right)^{0.22}
$$

The comparison of Equation (1) with Equation (2) is shown in Figure 8. It can be seen that within the range of $e_{0} / e_{L}=0.7-2.0$, the suction pressure calculated by Equation (1) is greater than that by Equation (2). This difference is mainly due to the extrapolation in the method proposed by Hong (2007). As shown in Figure 9, the method of back 
extrapolation proposed by Hong (2007) implies that the deformation can be neglected when the effective vertical stress is lower than the suction pressure (a horizontal line defined by $\ln \left(1+e_{0}\right)$ up to the suction pressure in the pre-suction state). Nevertheless, it is clear that the measured compression curves of reconstituted clays starting from a very small initial vertical stress show that the compression curve is not a horizontal line: compression deformation occurred in the pre-suction state, as shown in Figures 4 and 5. As a result, the intersection point determined by the extrapolating method from the post-suction straight line to the horizontal line of $\ln \left(1+e_{0}\right)$ proposed by Hong (2007) lies on the left of the intersection point of pre-suction state line and post-suction state line, as shown in Figure 9. The above comparison indicates that the value of the suction pressure given by Equation (1) is larger than that by Equation (2).

In order to further illustrate the difference in suction pressure between the method in this study and the method of Hong (2007), the values of suction pressure are determined by extrapolating the bilogarithmic straight line to the horizontal $\ln \left(1+e_{0}\right)$ lines as proposed in Hong (2007) by ignoring the experimental data in the pre-suction state. The results are shown in Figure 10. It can be seen that almost all suction pressures determined in this way are significantly lower than that predicted by Equation (1). Moreover, it can be seen that Equation (2) underestimates the suction pressures determined by the extrapolating method of Hong (2007). A similar result was reported by Hong (2007) who showed that the suction pressures obtained by the extrapolating method using test data available from literature lie above the line determined by Equation (2) which is derived based on the data on reconstituted Ariake clays.

Figure 11 shows the relationship between suction pressure and the void ratio at suction pressure normalised by the void ratio at liquid limit, $e_{S} / e_{L}$. The regression equation with a coefficient of correlation as high as 0.95 can be expressed as follows.

$$
\mathrm{e}_{\mathrm{s}} / \mathrm{e}_{\mathrm{L}}=2 /\left(\sigma_{\mathrm{s}}{ }^{\prime}\right)^{0.42}
$$

The above unique line is termed the suction pressure curve (SPC), which connects the pre-suction and the post-suction state compression curves for various reconstituted clays.

\section{NORMALISING COMPRESSION CURVES WITH INTRINSIC CONCEPT}

Burland (1990) introduced a powerful normalising index designated the void index $I_{v}$ to correlate the compression curves of various reconstituted clays with the void ratio at liquid limit $e_{L}$ ranging from 0.6 to 4.5 (i.e. $w_{L}=25 \%$ to $160 \%$ ). The void index is defined as follows.

$$
\mathrm{I}_{\mathrm{v}}=\left(\mathrm{e}-\mathrm{e}^{*}{ }_{100}\right) /\left(\mathrm{e}^{*}{ }_{100}-\mathrm{e}^{*}{ }_{1000}\right)=\left(\mathrm{e}-\mathrm{e}^{*}{ }_{100}\right) / \mathrm{C}_{\mathrm{c}}{ }^{*}
$$

where $e^{*} 100$ and $e^{*} 1000$ are the void ratios of the reconstituted clays at the effective vertical stresses of $100 \mathrm{kPa}$ and $1000 \mathrm{kPa}$, respectively; $C_{c}{ }^{*}$ is termed the intrinsic compression index. Burland (1990) reported that the compression curves can be normalised well by the void index for reconstituted clays with initial water contents of 1.0-1.5 times the liquid limits. The normalised compression curve can be expressed by a unique line in terms of void index against effective vertical stress, which is named the intrinsic compression line (ICL), and which can be represented by the 
following equation.

$$
\mathrm{I}_{\mathrm{v}}=2.45-1.285 \log \sigma_{v}{ }^{\prime}+0.015\left(\log \sigma_{v}{ }^{\prime}\right)^{3}
$$

where $\sigma_{v}{ }^{\prime}$ is expressed in $\mathrm{kPa}$. Burland (1990) suggested that ICL should be used only for effective vertical stress ranging from $10 \mathrm{kPa}$ to $4000 \mathrm{kPa}$.

Figure 12 shows the relationship of void index versus effective vertical stress for Lianyungang clay at different initial water contents. It can be seen that in the post-suction state lying on the right of the suction pressure curve (SPC), the $e$ - $\log \sigma_{v}{ }^{\prime}$ compression curves of various clays can be normalised well with respect to the void index. By contrast, it is not the case for the pre-suction state: the $I_{v}-\log \sigma_{v}{ }^{\prime}$ curve with a higher initial water content lies above that with a lower initial water content. It should be mentioned that the SPC in Figure 12 is expressed in terms of $I_{v}$ versus $\sigma_{\mathrm{s}}{ }^{\prime}$, where the values of $I_{v}$ were determined using the measured values of $e_{s}, e^{*} 100$ and $e^{*}{ }_{1000}$. Similar results can be found for Baimahu clay and Kemen clay (the figures are not shown here). It should be noted that the values of $e^{*} 100$ used in calculating $I_{v}$ are those directly measured at a vertical stress of $100 \mathrm{kPa}$ for all samples. However, the values of $e^{*} 1000$ are determined by interpolation for both Lianyungang clay and Baimahu clay based on the post-suction bilogarithmic line. For Kemen clay, the maximum effective vertical stress being $800 \mathrm{kPa}$, the values of $e^{*} 1000$ are determined by extrapolation based on the post-suction bilogarithmic line. Fortunately, regression analysis based on the oedometer test data show a high coefficient of linear correlation (i.e. larger than $0.99)$ between $\ln (1+e)$ and $\log \sigma_{v}{ }^{\prime}$ for all clays in the post-suction state. The error caused by interpolation or extrapolation is thus considered to be negligible.

The compression curves normalised with respect to void index for the different clays at different initial water contents in the post-suction state are compared with the ICL, as shown in Figure 13. It can be seen that the void index can indeed be used as a powerful index for correlating the compression curves. When the effective vertical stress is larger than $25 \mathrm{kPa}$, the experimental results form a reasonably unique line. Interestingly, this line is almost identical to the ICL proposed by Burland (1990). Within the range from $1.5 \mathrm{kPa}$ to about $10 \mathrm{kPa}$, the experimental data are to a certain extent scattered and lie a little above the ICL. However, the regression analysis gives a coefficient of correlation $r$ as high as 0.99 when normalising the compression curves within the range of $1.5 \mathrm{kPa}-1600 \mathrm{kPa}$. The regressed equation is expressed as follows.

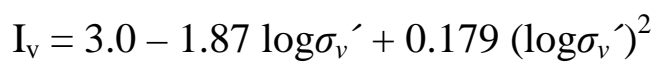

where $\sigma_{v}{ }^{\prime}$ is expressed in $\mathrm{kPa}$. This line is referred to as the extended intrinsic compression line (EICL), which extends the ICL of Burland (1990) to an effective vertical stress as low as $1.5 \mathrm{kPa}$.

\section{DISCUSSION ON INTRINSIC PARAMETERS}

As can be seen from the definition of void index, the $e^{*} 100$ and the $C_{c}{ }^{*}$ are essential for determining $I_{v}$. Since the ICL or EICL is not routinely measured, Burland (1990) suggested that $e^{*} 100$ and $C_{c}{ }^{*}$ may be estimated using the following empirical equations when test results are not available.

$$
\mathrm{e}^{*}{ }_{100}=0.109+0.679 \mathrm{e}_{\mathrm{L}}-0.089 \mathrm{e}_{\mathrm{L}}{ }^{2}+0.016 \mathrm{e}_{\mathrm{L}}^{3}
$$




$$
\mathrm{C}_{\mathrm{c}}{ }^{*}=\left(\mathrm{e}^{*}{ }_{100}-\mathrm{e}^{*}{ }_{1000}\right)=0.256 \mathrm{e}_{\mathrm{L}}-0.04
$$

The results of oedometer tests on four clays at initial water contents of $1 \times w_{L}, 1.25 \times w_{L}$, $1.5 \times w_{L}$ and $1.75 \times w_{L}$ obtained by Certo and Lutenegger (2004) illustrated that the values of $e^{*} 100$ and $e^{*} 1000$ can be significantly affected by the initial water contents. The results shown in Figure 4 also indicate that the positions of $e^{*} 100$ and $e^{*} 1000$ for a higher initial water content lie above those for a lower initial water content. The relationships of $e^{*} 100$ versus initial water content $w_{0}$ and $C_{c}{ }^{*}$ versus $w_{0}$ for the investigated clays with different liquid limits are presented in Figures 14 and 15 respectively. As can be seen, the values of both $e^{*} 100$ and $C_{c}{ }^{*}$ increases with the increase in initial water content for a given clay. It can also be seen that $e^{*} 100$ and $C_{c}{ }^{*}$ for a clay with a larger liquid limit are greater than those for a clay with a lower liquid limit. These observations suggest that both initial water content and liquid limit affect the parameters $e^{*} 100$ and $C_{c}{ }^{*}$, in agreement with the results of Certo and Lutenegger (2004).

Figures 16 and 17 show the comparisons between the measured and the calculated values of $e^{*}{ }_{100}$ and $C_{c}{ }^{*}$ respectively. Note that the calculations are made using Equations (7) and (8) by considering an initial water content of $1.25 \times w_{L}$. The calculated values of $e^{*} 100$ are consistent with the measured values. But the calculated values of $C_{c}{ }^{*}$ are smaller than the measured values, especially for Lianyungang clay and Baimahu clay. It appears that the rational empirical methods of predicting the parameters by accounting for the effects of both initial water content and liquid limit need more experimental results and future studies.

\section{CONCLUSIONS}

The $e-\log \sigma_{v}{ }^{\prime}$ compression curves starting from a very low effective vertical stress of $0.5 \mathrm{kPa}$ for reconstituted clays at initial water contents of 0.7-2.0 times their liquid limits show an inverse "S" shape, similar to soft natural clays. These inverse S-shaped $e-\log \sigma_{v}{ }^{\prime}$ compression curves can be well represented by two straight lines in the bilogarithmic plot.

The effective vertical stress corresponding to the intersection point of the two straight lines in the bilogarithmic graph is the suction pressure $\sigma_{s}{ }^{\prime}$, which has a reasonably unique relationship with the initial void ratio normalised with respect to the void ratio at liquid limit $e_{0} / e_{L}$. The unique relationship can be expressed as $\sigma_{s}{ }^{\prime}$ $(\mathrm{kPa})=5.66 /\left(e_{0} / e_{L}\right)^{2}$.

The suction pressure curve (SPC) corresponds to the starting points of compression curves in the post-suction state, which can be expressed by $e_{S} / e_{L}=$ $2 /\left(\sigma_{s}{ }^{\prime}\right)^{0.42}$. The SPC is derived based on the unique relationship of suction pressure $\sigma_{s}{ }^{\prime}$ versus the void ratio at suction pressure $e_{s}$ normalised with respect to the void ratio at liquid limit $e_{L}$.

The void index proposed by Burland (1990) is a powerful index for correlating the compression curves of various reconstituted clays at initial water contents of 0.7-2.0 times their liquid limits, if the effective vertical stress is larger than the suction pressure (i.e. the post-suction state).

The extended intrinsic compression line (EICL) expressed by $I_{v}=$ 
$3.0-1.87 \times \log \sigma_{v}{ }^{\prime}+0.179 \times\left(\log {\sigma_{v}}^{\prime}\right)^{2}$ is proposed allowing extension of the ICL to lower effective vertical stresses than that considered by Burland (1990). Indeed, when the effective vertical stress is higher than $25 \mathrm{kPa}$, the EICL is almost identical to the ICL, but the former lies a little above the latter for vertical stresses lower than $25 \mathrm{kPa}$.

\section{ACKNOWLEDGEMENTS}

This study is supported by the National Natural Science Foundation of China (Grant No. 50878050). The authors are grateful to Dr Yongfeng Deng, Mr Jianwen Ding, Mr Shuai Zhang, Mr Qinghua Wang and Mr Guizhong Xu for their help and useful discussions.

\section{REFERENCES}

1) Alonso, E.E., Gens, A. and Hight, D.W. (1987). Special problem soils. General report. Comptes Rendus de la 9ème Conference Européenne de Mécanique des Sols et des Travaux de Fondations, 3, 1087-1146, Dublin.

2) Alonso, E.E., Gens, A. and Josa, A. (1990). A constitutive model for partially saturated soils. Géotechnique 40 (3), 405-430.

3) Buchan, S. and Smith, D. T. (1999). Deep-sea sediment compression curves: some controlling factors, spurious overconsolidation, predictions, and geophysical reproduction. Marine Georesources and Geotechnology 17, No. 1, 65-81.

4) Burland, J. B. (1990). On the compressibility and shear strength of natural clays. Géotechnique 40, No. 3, 329-378.

5) Butterfield, R. (1979). A natural compression law for soils. Géotechnique 29, No. 4, 469-480.

6) Cerato, A. B. and Lutenegger, A. J. (2004). Determining intrinsic compressibility of fine-grained soils. Journal of Geotechnical and Geoenvironmental Engineering, Proc. Am. Soc. Civ. Engrs 130, No. 8, 872-877.

7) Chandler, R. J. (2000). Clay sediments in depositional basin: the Geotechnical Cycle. The Quarterly Journal of Engineering Geology and Hydrology 33, No. 1, 7-39.

8) Cotecchia, F. and Chandler, R. J. (1997). The influence of structure on the pre-failure behaviour of a natural clay. Géotechnique 47, No. 3, 523-544.

9) Cotecchia, F. and Chandler, R. J. (2000). A general framework for the mechanical behaviour of clays. Géotechnique 50, No. 4, 431-447.

10) Cui, Y. J. and Delage, P. (1996). Yielding and plastic behaviour of an unsaturated compacted silt. Géotechnique 46, No. 2, 291-311.

11) Grim, R.E. (1962). Applied clay mineralogy, McGraw-Hill Co., Inc., New York.

12) Head, K. H. (1992). Manual of Soil Laboratory Testing: Soil Classification and Compaction Tests ( $2^{\text {nd }}$ edition). London: Pentech Press Limited.

13) Hight, D. W., Jardine, R. J. and Gens, A. (1987). The behaviour of soft clays. Chapter 2, Embankment on soft clays, pp. 33-158. Athens: Public Works Research Centre of Greece.

14) Hight, D. W., Böese, R., Butcher, A. P., Clayton, C. R. I. and Smith, P. R. (1992). Disturbance of the Bothkennar clay prior to laboratory testing. Géotechnique 42, 
No. 2, 199-217.

15) Holtz, R. D., Jamiolkowski, M. and Lancellotta, R. (1986). Lessons from oedometer tests on high quality samples. Journal of Geotechnical Engineering Division, Proc. Am. Soc. Civ. Engrs 112, No. 8, 768-776.

16) Hong, Z. and Onitsuka, K. (1998). A method of correcting yield stress and compression index of Ariake clays for sample disturbance. Soils and Foundations 38, No. 2, 211-222.

17) Hong, Z. and Tsuchida, T. (1999). On compression characteristics of Ariake clays. Canadian Geotechnical Journal 36, No. 5, 807-814.

18) Hong, Z. (2007). Void Ratio-Suction Behavior of Remolded Ariake Clays. Geotechnical Testing Journal 30, No. 3, 234-239.

19) Houston, W. N. and Mitchell, J. K. (1969). Property interrelationships in sensitive clays. Journal of the Soil Mechanics and Foundations Division, Proc. Am. Soc. Civ. Engrs 95, No. 4, 1037-1062.

20) Leroueil, S., Tavenas, F., Brucy, F., La Rochelle, P., and Roy, M. (1979). Behavior of destructured natural clays. Journal of Geotechnical Engineering, Proc. Am. Soc. Civ. Engrs 105, No. 6, 759-778.

21) Leroueil, S., Tavenas, F. and Le Bihan, J.P. (1983). Propriétés caractéristiques des argiles de l'est du Canada. Canadian Geotechnical Journal 20, No. 4, 681-705.

22) Leroueil, S., Tavenas, F. and Locat, J. (1985). Discussion on "Correlations between index tests and the properties of remolded clays". Géotechnique 35, No. 2, 223-226.

23) Leroueil, S. and Vaughan, P. R. (1990). The general and congruent effects of structure in natural soils and weak rocks. Géotechnique 40, No. 3, pp. 467-488.

24) Locat, J. and Lefebvre, G. (1986). The origin of structuration of the Grande-Baleine marine sediments, Québec, Canada. Q. J. Engng. Geol. 19, No. 4, 365-374.

25) Locat, J. and Demers, D. (1988). Viscosity, yield stress, remolded strength, and liquidity index relationships for sensitive clays. Canadian Geotechnical Journal 25, No. 4, 799-806.

26) Mitchell, K. (1993). Fundamentals of soil behavior ( $2^{\text {nd }}$ edition). New York: John Wiley \& Sons, Inc.

27) Nagaraj, T. S. and Srinivasa Murthy, B. R. (1986). A critical reappraisal of compression index equation. Géotechnique 36, No. 1, 27-32.

28) Onitsuka, K., Hong, Z., Hara, Y. and Yoshitake, S. (1995). Interpretation of oedometer test data for natural clays. Soils and Foundations 35, No. 3, 61-70.

29) Pelletier, J. H., Oslon, R. E. and Rixner, J. J. (1979). Estimation of consolidation properties of clay from field observation. Geotechnical Testing Journal 2, No. 1, 34-43.

30) Russel, E. R. and Mickle, J. L. (1970). Liquid Limit Values by Soil Moisture Tension. Journal of the Soil Mechanics and Foundations Division, Proc. Am. Soc. Civ. Engrs 96, No. 3, 967-989.

31) Schmertmann, J. H. (1991). The mechanical aging of soils. Journal of Geotechnical Engineering, Proc. Am. Soc. Civ. Engrs. 117, No. 9, 1288-1330. 
32) Skempton, A. W. and Northey, R. D. (1953). The sensitivity of clays. Géotechnique 3, No. 1, 30-53.

33) Skempton, A. W. (1970). The consolidation of clays by gravitational compaction. Q. J. Geol. Soc. 125, 373-411.

34) Sridharan, A. and Prakash, K. (1996). Discussion on "interpretation of oedometer test data for natural clays." Soils and Foundations 36, No. 3, 146-148.

35) Tsuchida, T. and Gomyo, M. (1995). Unified model of e-log p relationship with the consolidation of the effect of initial void ratio. Proc. Int. Symp. on Compression and Consolidation of Clayey Soils - IS-Hiroshima'95, Japan, 379-384.

36) Whyte, I. L. (1982). Soil plasticity and strength - a new approach using extrusion. Ground Engineering 15, No. 1, 16-24.

37) Wroth, C. P. and Wood, D.W. (1978). The correlation of index properties with some basic engineering properties of soils. Canadian Geotechnical Journal 15, No. 2, 137-145.

\section{List of Tables and Figures}

Table 1. Basic physical properties of reconstituted clays

Table 2. Initial water contents of reconstituted clays

Fig. 1. Sampling sites

Fig. 2. Plasticity chart

Fig. 3. Schematic diagramme of (a) modified oedometer; (b) soil specimen box

Fig. 4. Compression curves of three reconstituted clays at different initial water contents

Fig. 5. Bilogarithmic compression curves of three reconstituted clays at different initial water contents

Fig. 6. Change in suction pressure with initial water content

Fig. 7. Relationship between suction pressure and normalised initial void ratio

Fig. 8. Comparison of calculated suction pressures

Fig. 9. Schematic plot of two methods in determining suction pressure

Fig. 10. Suction pressures determined by the extrapolating method of Hong (2007) based on the post-suction test data from this study

Fig. 11. Relationship between suction pressure and $\mathrm{e}_{\mathrm{s}} / \mathrm{e}_{\mathrm{L}}$

Fig. 12. Relationship of void index versus effective vertical stress for Lianyungang clay at different initial water contents

Fig. 13. Comparison of normalised compression curves with ICL 
Fig. 14. Relationships of $e^{*} 100$ versus initial water content for different clays Fig. 15. Relationships of $C_{c}{ }^{*}$ versus initial water content for different clays Fig. 16. Relationships of $e^{*} 100$ versus normalised initial void ratio

Fig. 17. Relationships of $C_{c}{ }^{*}$ versus normalised initial void ratio 
Table 1. Basic physical properties of reconstituted clays

\begin{tabular}{ccccccc}
\hline Soils & $\begin{array}{c}\text { Density of soil particles } \\
\left(\mathrm{Mg} / \mathrm{m}^{3}\right)\end{array}$ & $\begin{array}{c}\text { Liquid limit } \\
(\%)\end{array}$ & $\begin{array}{c}\text { Plastic limit } \\
(\%)\end{array}$ & $\begin{array}{c}\text { Sand }(0.06-2 \mathrm{~mm}) \\
(\%)\end{array}$ & $\begin{array}{c}\text { Silt }(0.002-0.06 \mathrm{~mm}) \\
(\%)\end{array}$ & $\begin{array}{c}\text { Clay }(<0.002 \mathrm{~mm}) \\
(\%)\end{array}$ \\
\hline \hline Lianyungang clay & 2.71 & 74 & 33 & 1 & 76 & 23 \\
Baimahu clay & 2.65 & 91 & 38 & 6 & 74 & 20 \\
Kemen clay & 2.67 & 61 & 30 & 8 & 73 & 19 \\
\hline
\end{tabular}


Table 2. Initial water contents of reconstituted clays

\begin{tabular}{|c|c|c|c|}
\hline Soils & $\begin{array}{c}\text { Initial water content } \\
\mathrm{w}_{0}(\%)\end{array}$ & $\begin{array}{l}\text { Liquid limit } \\
\mathrm{w}_{\mathrm{L}}(\%)\end{array}$ & $\mathrm{w}_{0} / \mathrm{w}_{\mathrm{L}}$ \\
\hline Lianyungang clay & 146 & $\overline{774}$ & 1.97 \\
\hline Lianyungang clay & 142 & 74 & 1.92 \\
\hline Lianyungang clay & 135 & 74 & 1.82 \\
\hline Lianyungang clay & 127 & 74 & 1.72 \\
\hline Lianyungang clay & 119 & 74 & 1.61 \\
\hline Lianyungang clay & 114 & 74 & 1.54 \\
\hline Lianyungang clay & 104 & 74 & 1.41 \\
\hline Lianyungang clay & 96 & 74 & 1.30 \\
\hline Lianyungang clay & 92 & 74 & 1.24 \\
\hline Lianyungang clay & 85 & 74 & 1.15 \\
\hline Lianyungang clay & 78 & 74 & 1.05 \\
\hline Lianyungang clay & 68 & 74 & 0.92 \\
\hline Lianyungang clay & 59 & 74 & 0.80 \\
\hline Lianyungang clay & 50 & 74 & 0.68 \\
\hline Baimahu clay & 180 & 91 & 1.98 \\
\hline Baimahu clay & 174 & 91 & 1.91 \\
\hline Baimahu clay & 163 & 91 & 1.79 \\
\hline Baimahu clay & 153 & 91 & 1.68 \\
\hline Baimahu clay & 143 & 91 & 1.57 \\
\hline Baimahu clay & 137 & 91 & 1.51 \\
\hline Baimahu clay & 126 & 91 & 1.38 \\
\hline Baimahu clay & 119 & 91 & 1.31 \\
\hline Baimahu clay & 111 & 91 & 1.22 \\
\hline Baimahu clay & 101 & 91 & 1.11 \\
\hline Baimahu clay & 91 & 91 & 1.00 \\
\hline Baimahu clay & 83 & 91 & 0.91 \\
\hline Baimahu clay & 72 & 91 & 0.79 \\
\hline Baimahu clay & 64 & 91 & 0.70 \\
\hline Kemen clay & 122 & 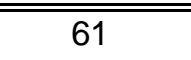 & 2.00 \\
\hline Kemen clay & 116 & 61 & 1.90 \\
\hline Kemen clay & 110 & 61 & 1.80 \\
\hline Kemen clay & 106 & 61 & 1.74 \\
\hline Kemen clay & 99 & 61 & 1.62 \\
\hline Kemen clay & 91 & 61 & 1.49 \\
\hline Kemen clay & 87 & 61 & 1.43 \\
\hline Kemen clay & 80 & 61 & 1.31 \\
\hline Kemen clay & 72 & 61 & 1.18 \\
\hline Kemen clay & 66 & 61 & 1.08 \\
\hline Kemen clay & 62 & 61 & 1.02 \\
\hline Kemen clay & 57 & 61 & 0.93 \\
\hline Kemen clay & 48 & 61 & 0.79 \\
\hline Kemen clay & 43 & 61 & 0.70 \\
\hline
\end{tabular}




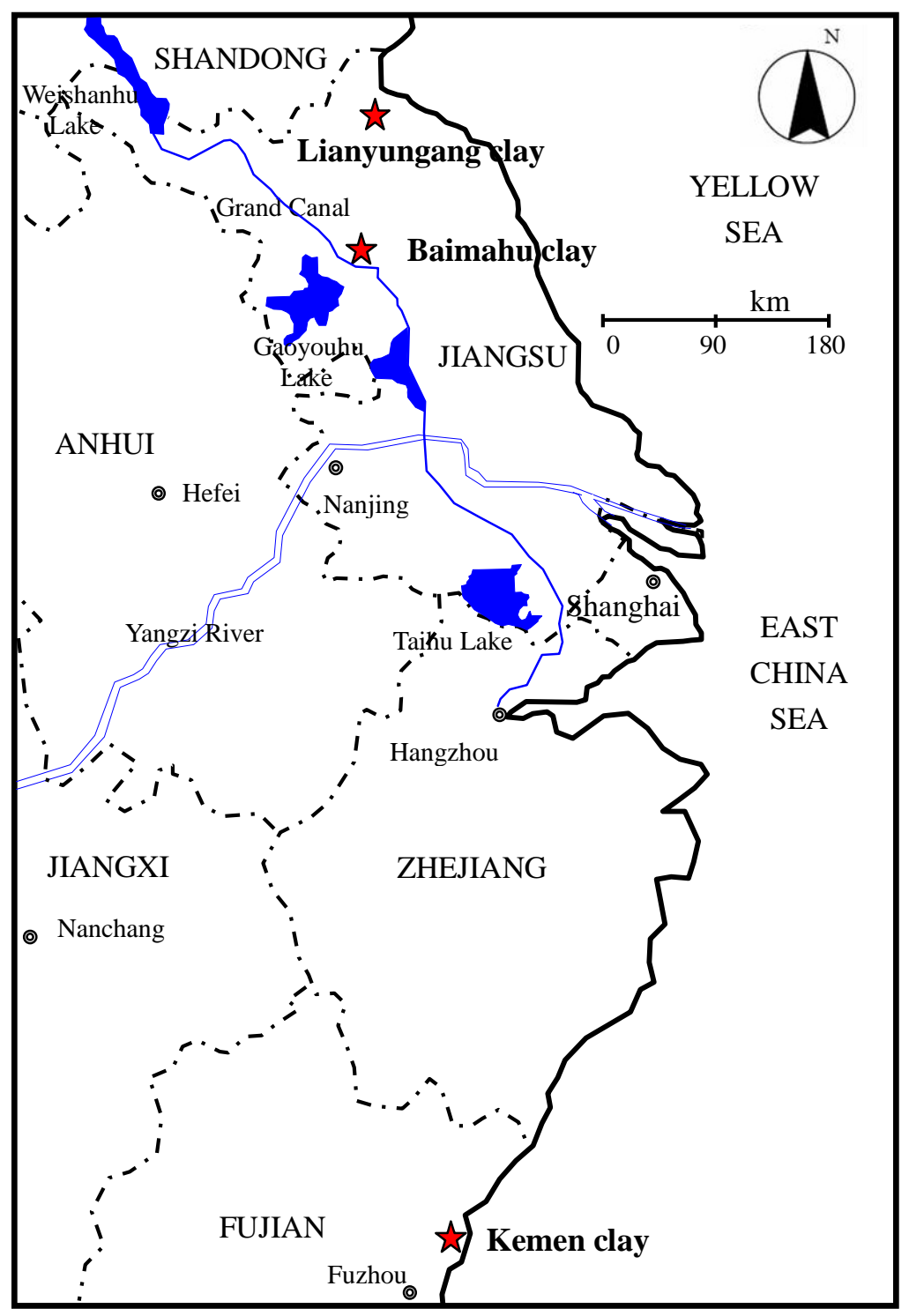

Fig. 1. Sampling sites 


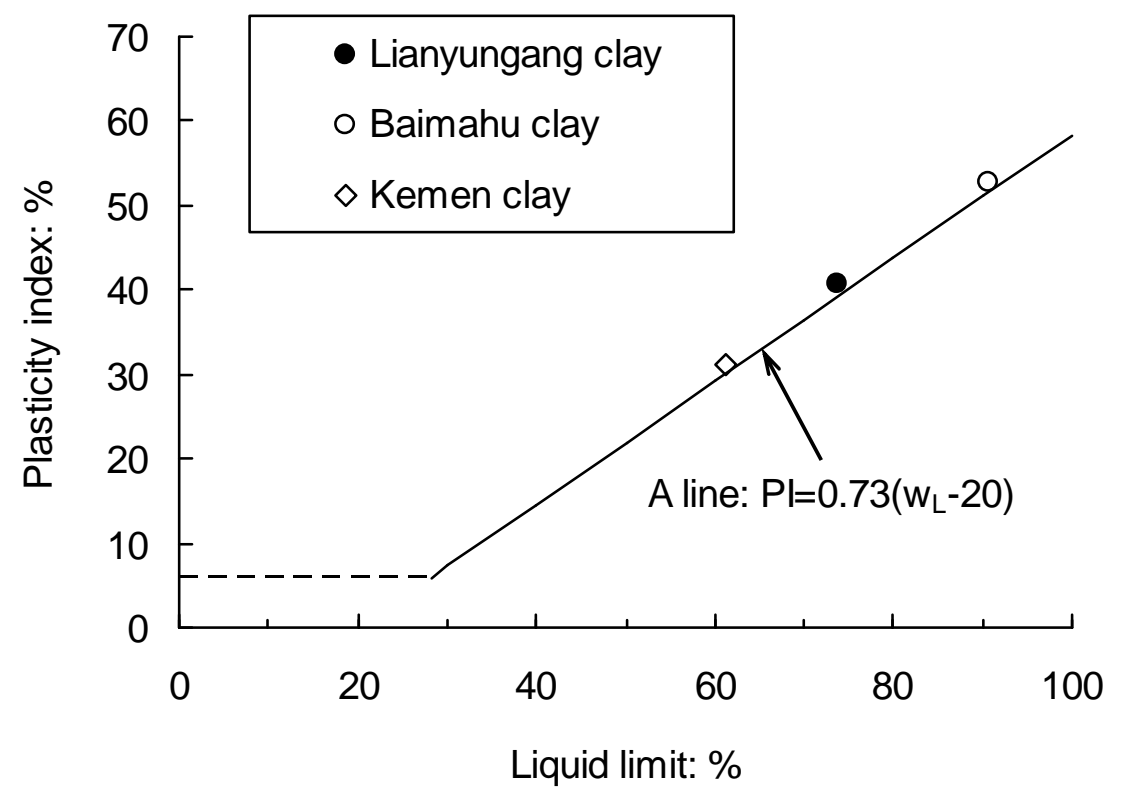

Fig. 2. Plasticity chart 


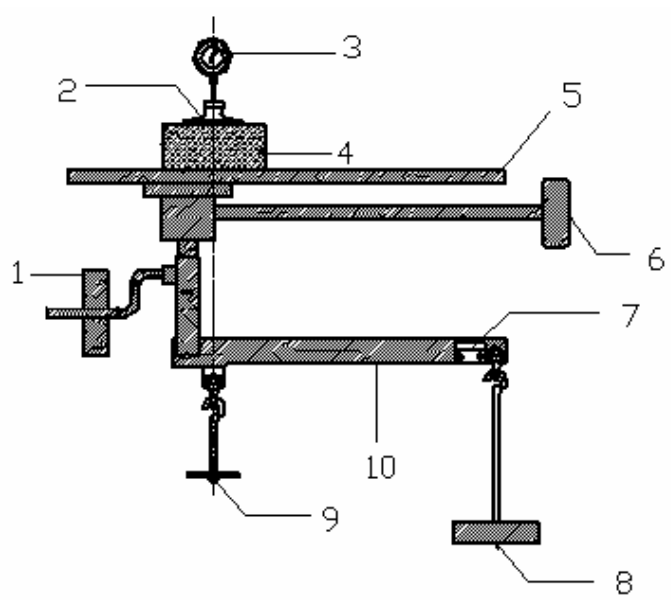

1. Hammer balance 2. Laoding-pressure head

3. Dial indicator

4. Soil specimen box

5. Board units

6. Handwheel

7. Long quasi-bubble 8 . Second weight hanger system

9. First weight hanger system

10. Leverage (1:12)

(a)

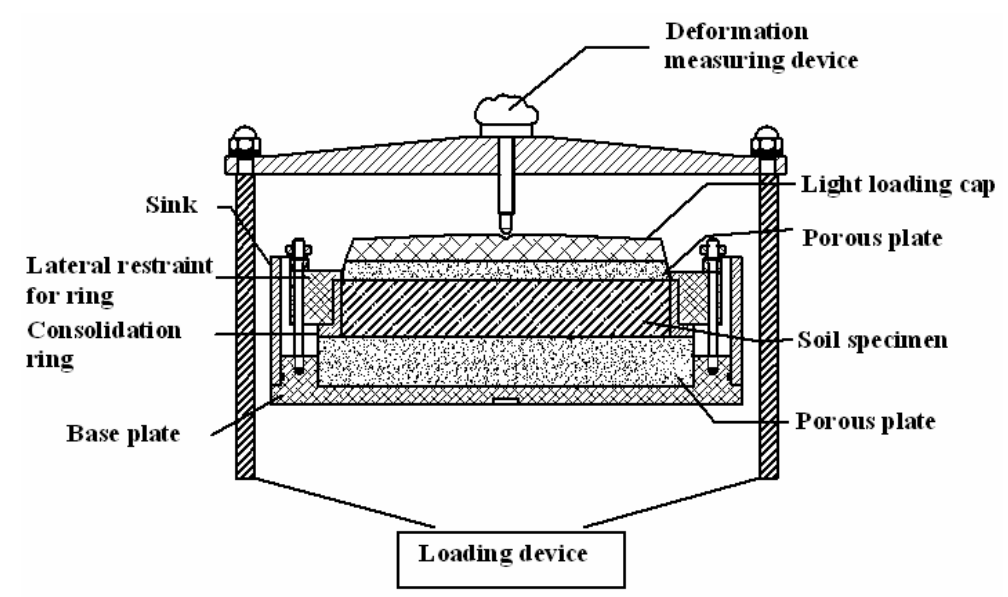

(b)

Fig. 3. Schematic diagramme of (a) modified oedometer; (b) soil specimen box 


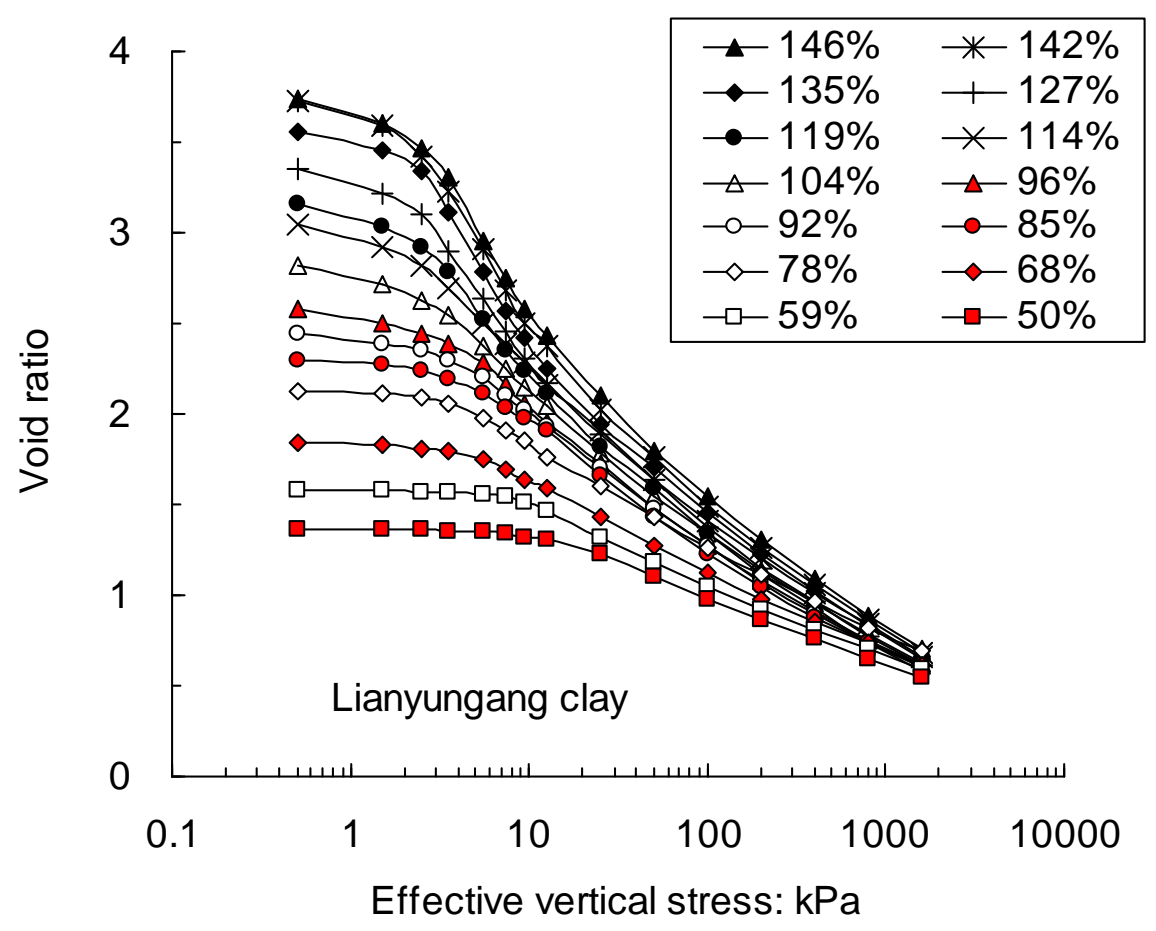

(a) Lianyungang clay

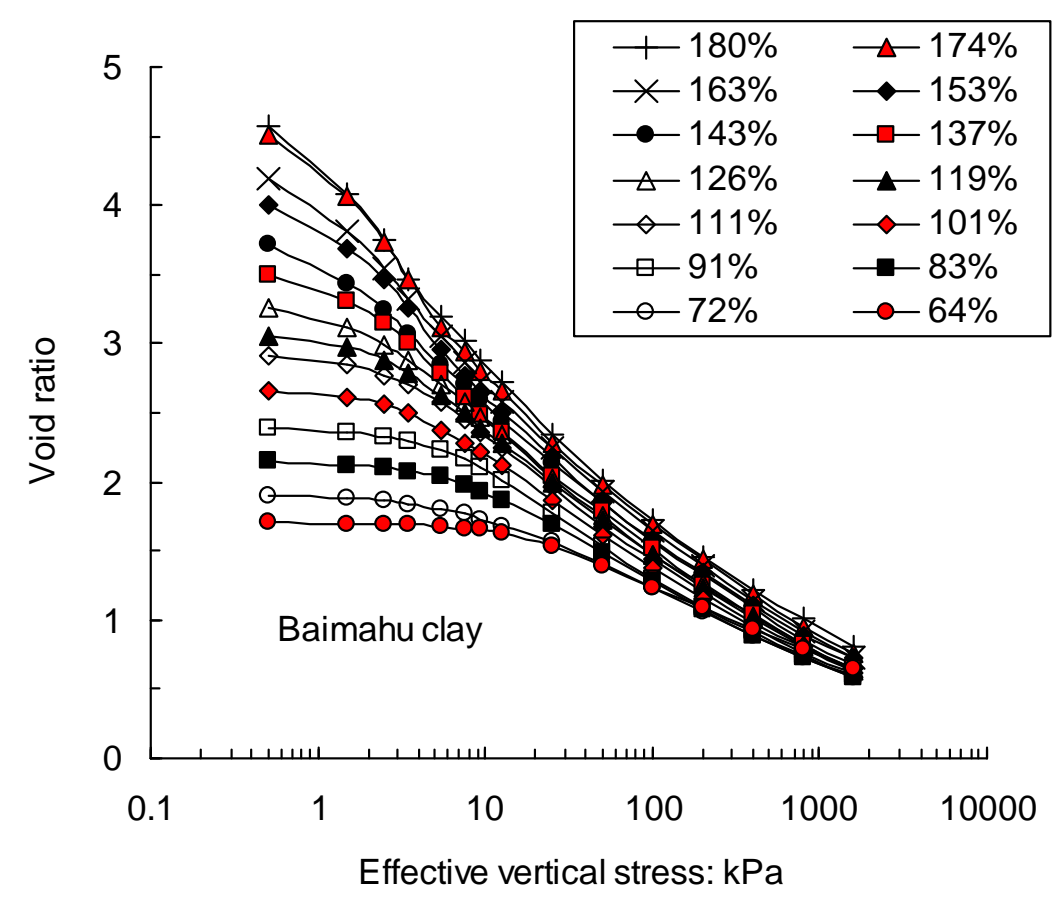

(b) Baimahu clay 


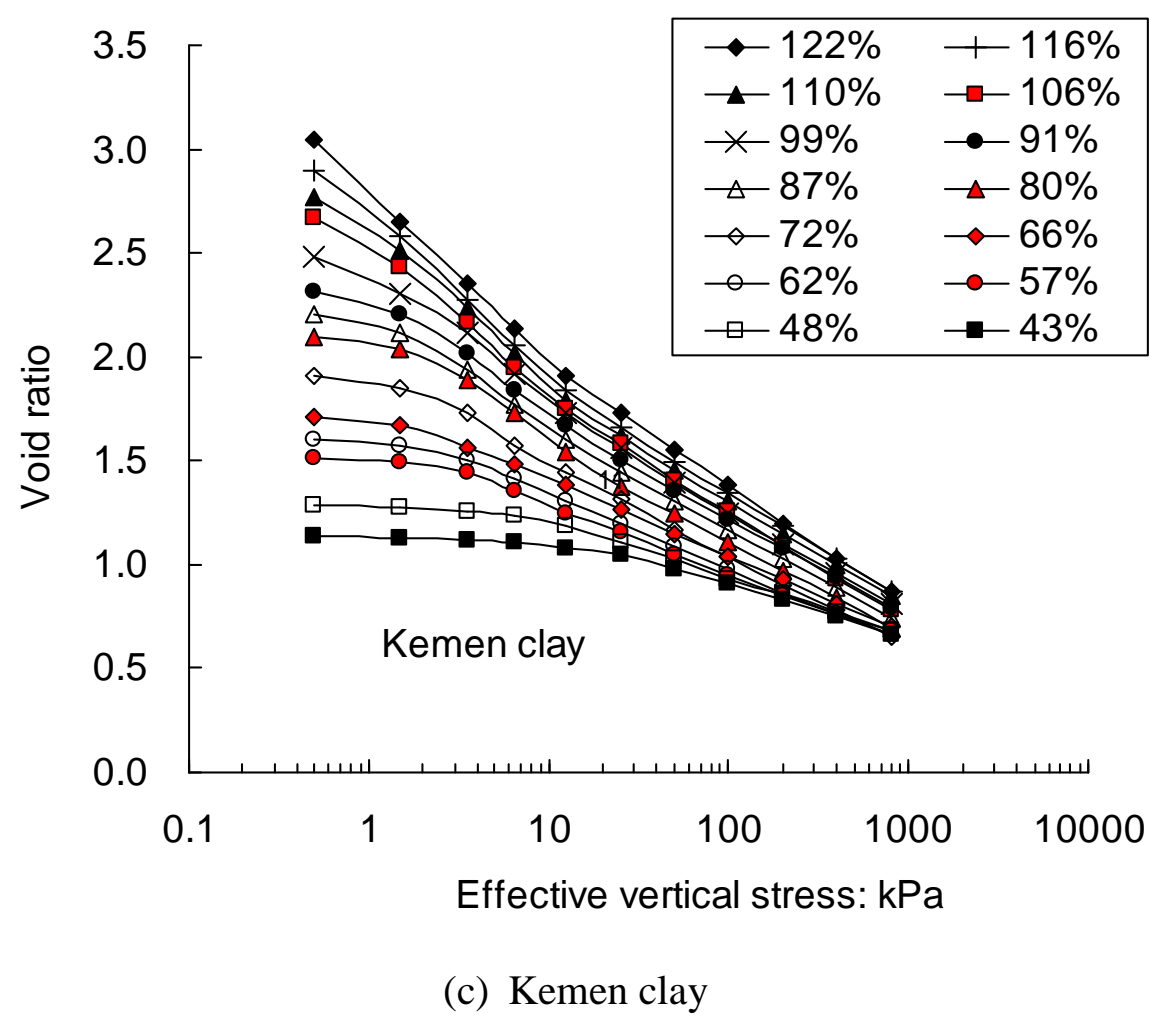

Fig. 4. Compression curves of three reconstituted clay at different initial water contents 


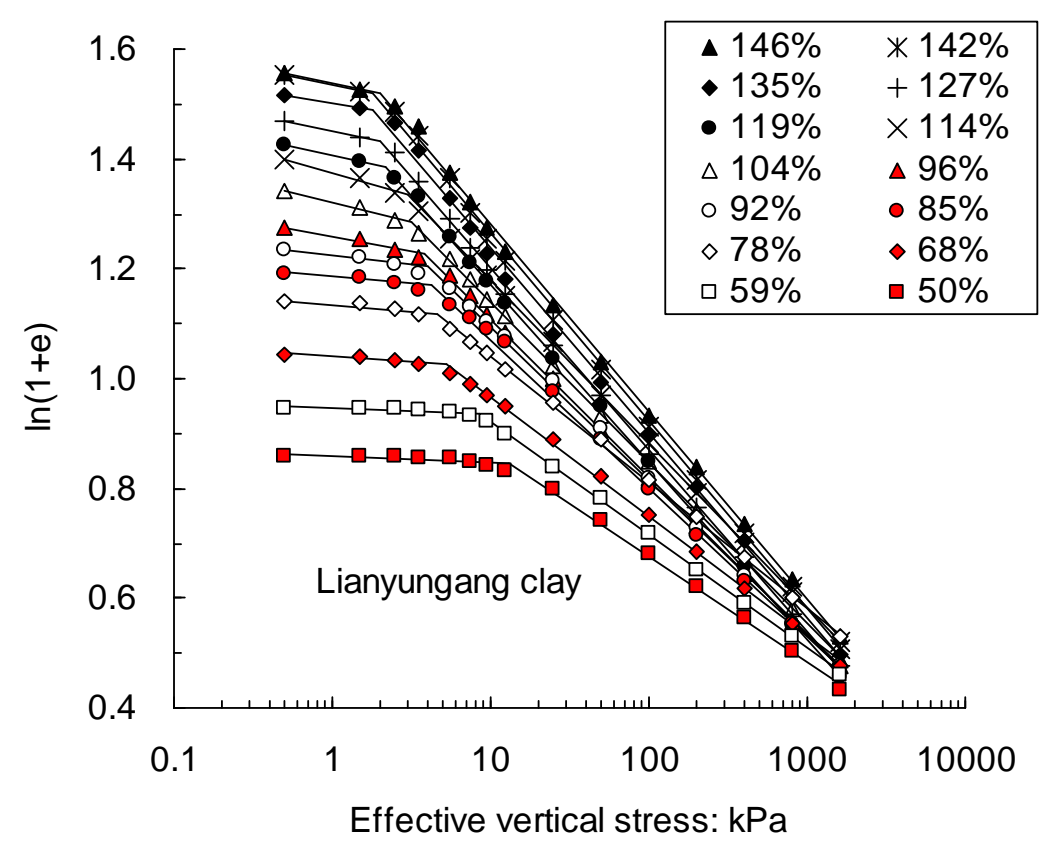

(a) Lianyungang clay

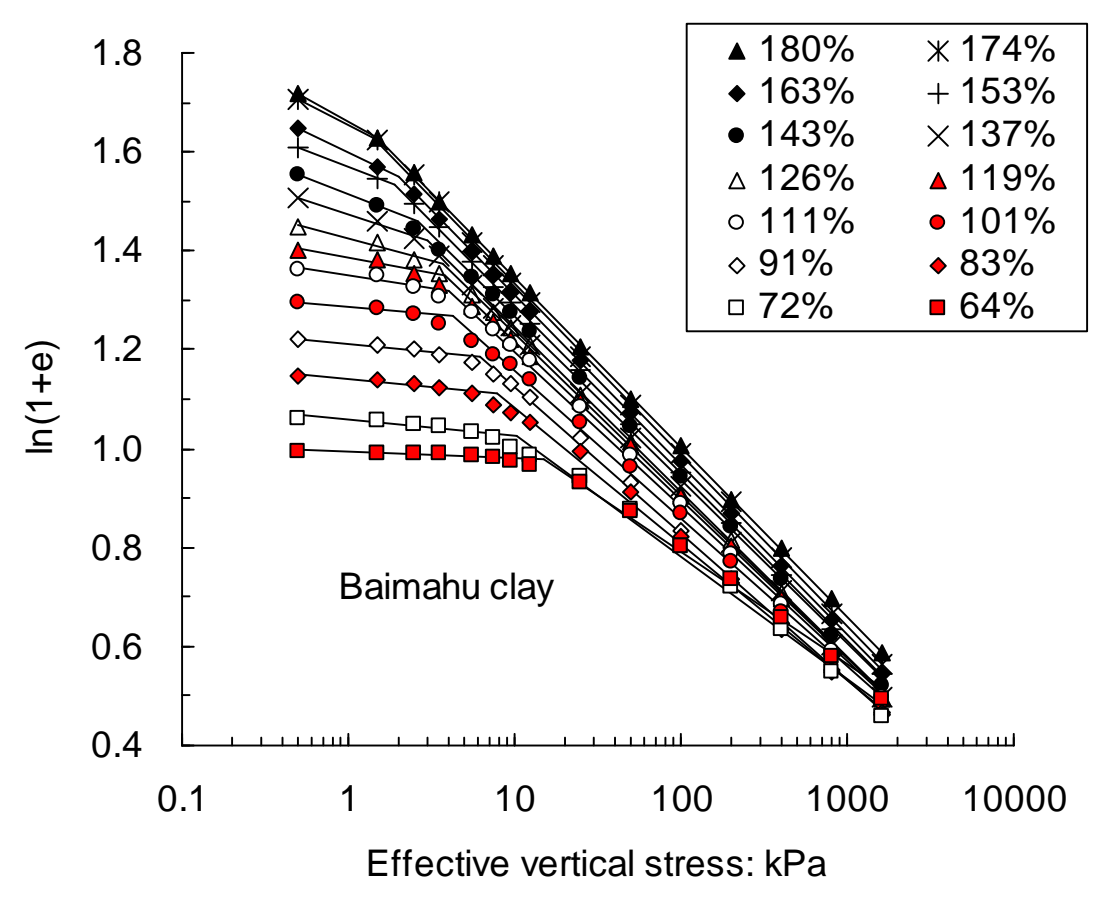

(b) Baimahu clay 


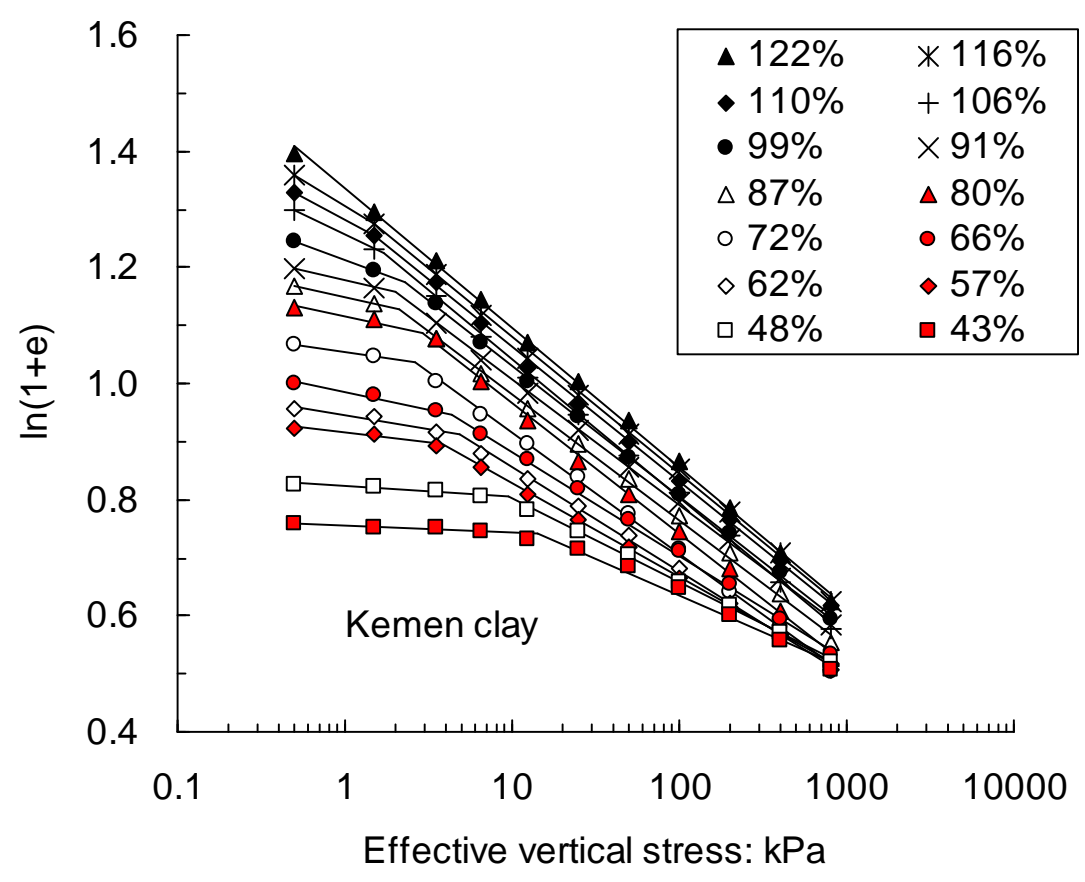

(c) Kemen clay

Fig. 5. Compression curves of three reconstituted clays at different initial water contents 


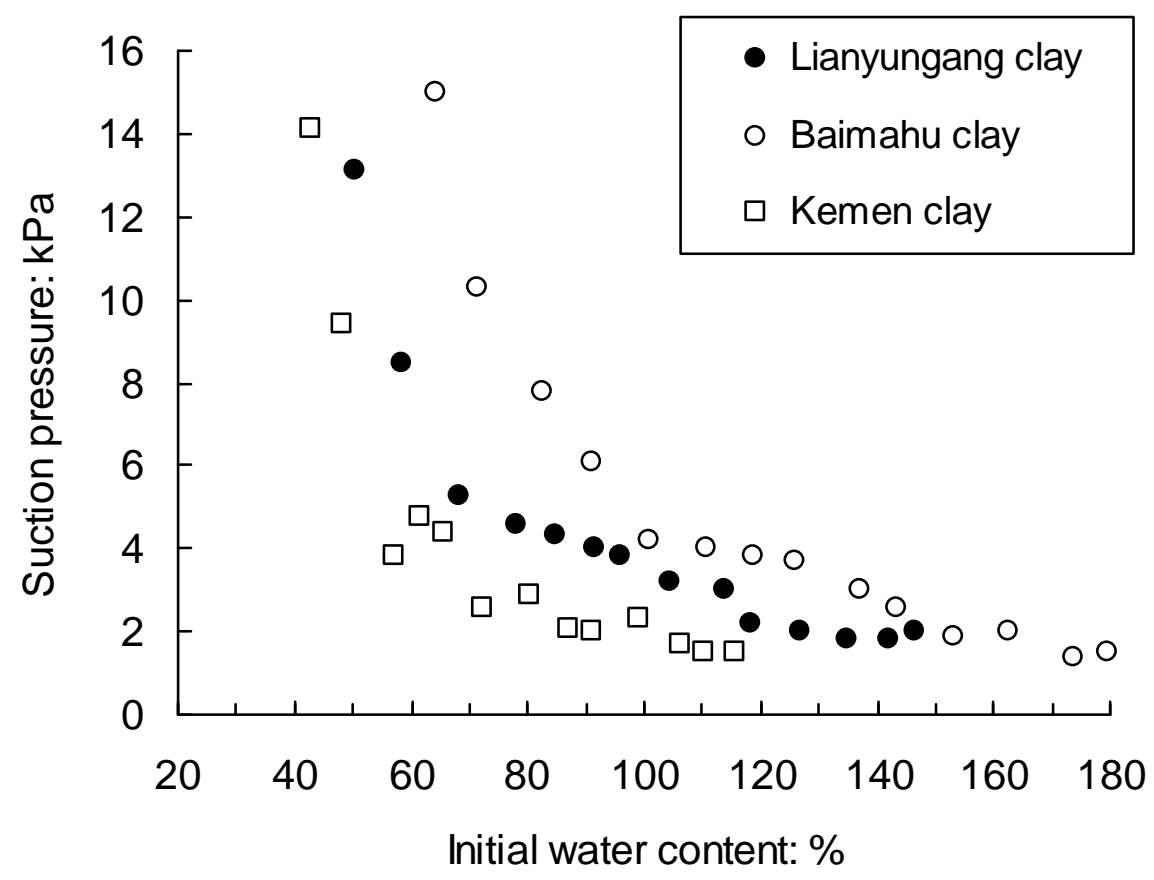

Fig. 6. Change in suction pressure with initial water content 


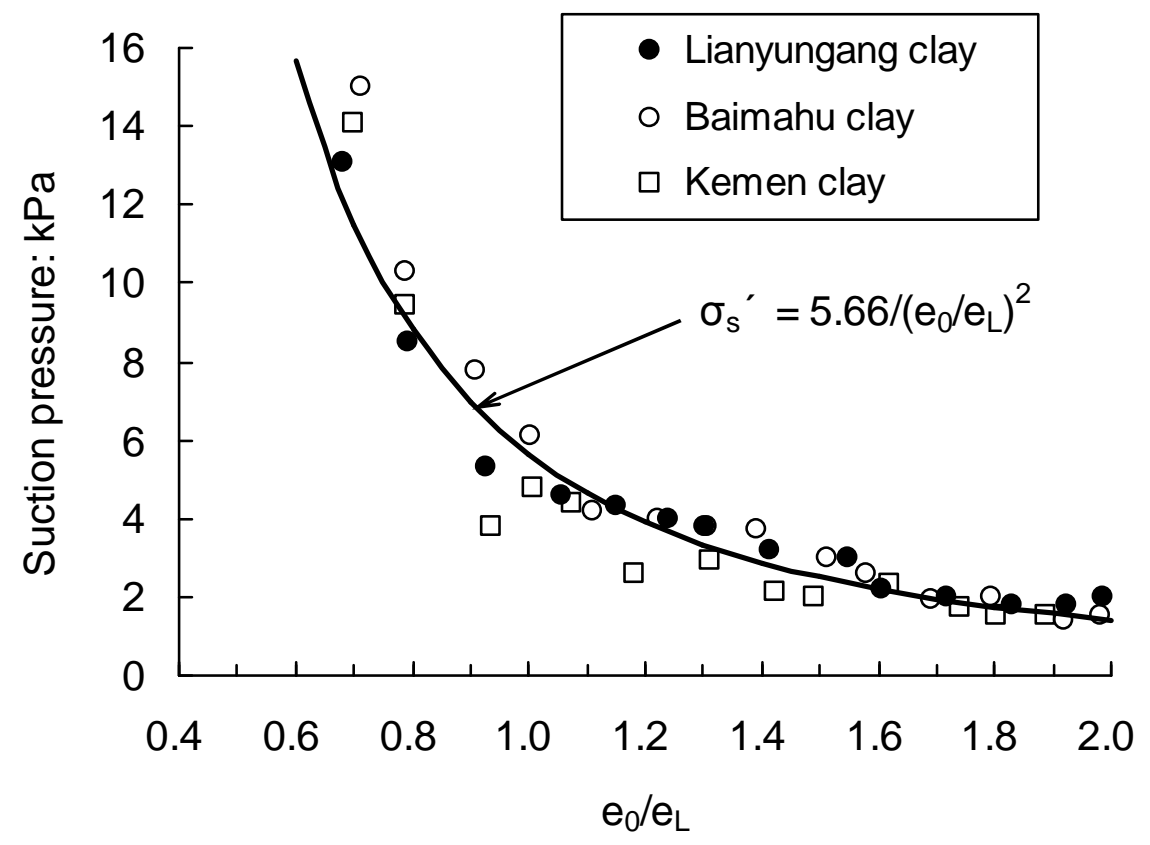

Fig. 7. Relationship between suction pressure and normalised initial void ratio 


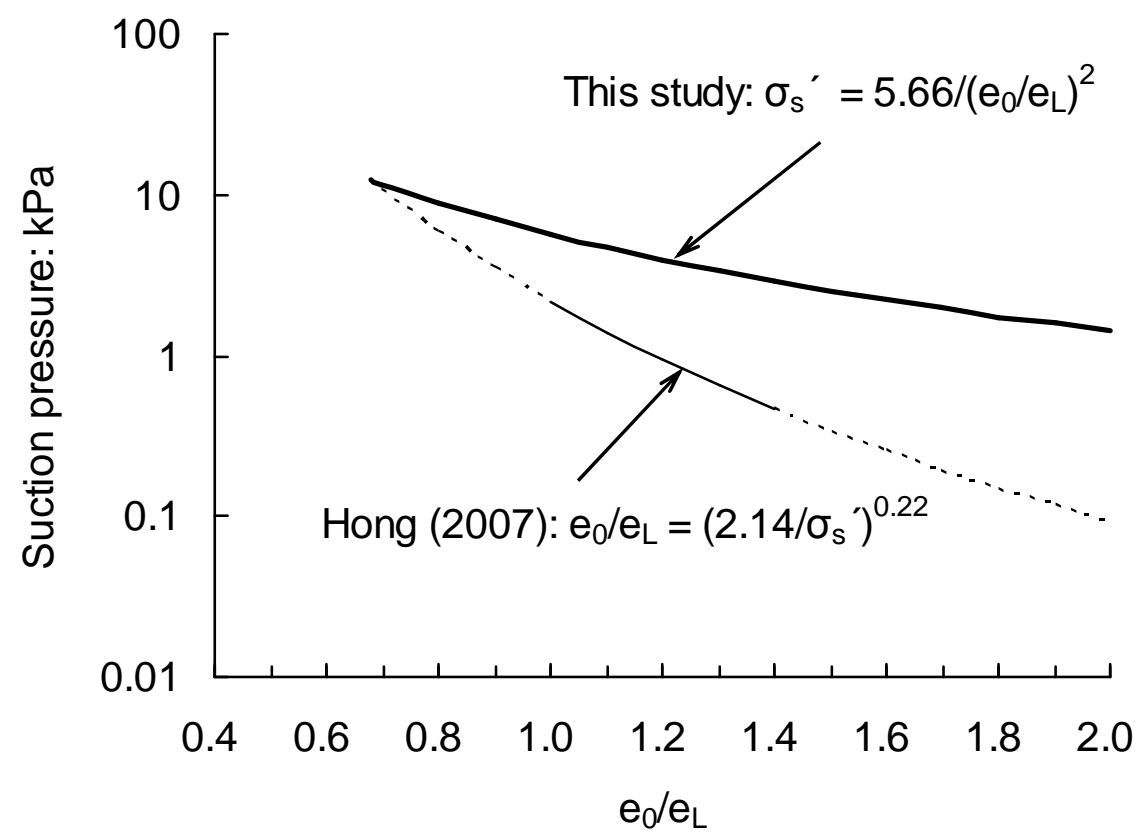

Fig. 8. Comparison of calculated suction pressures 


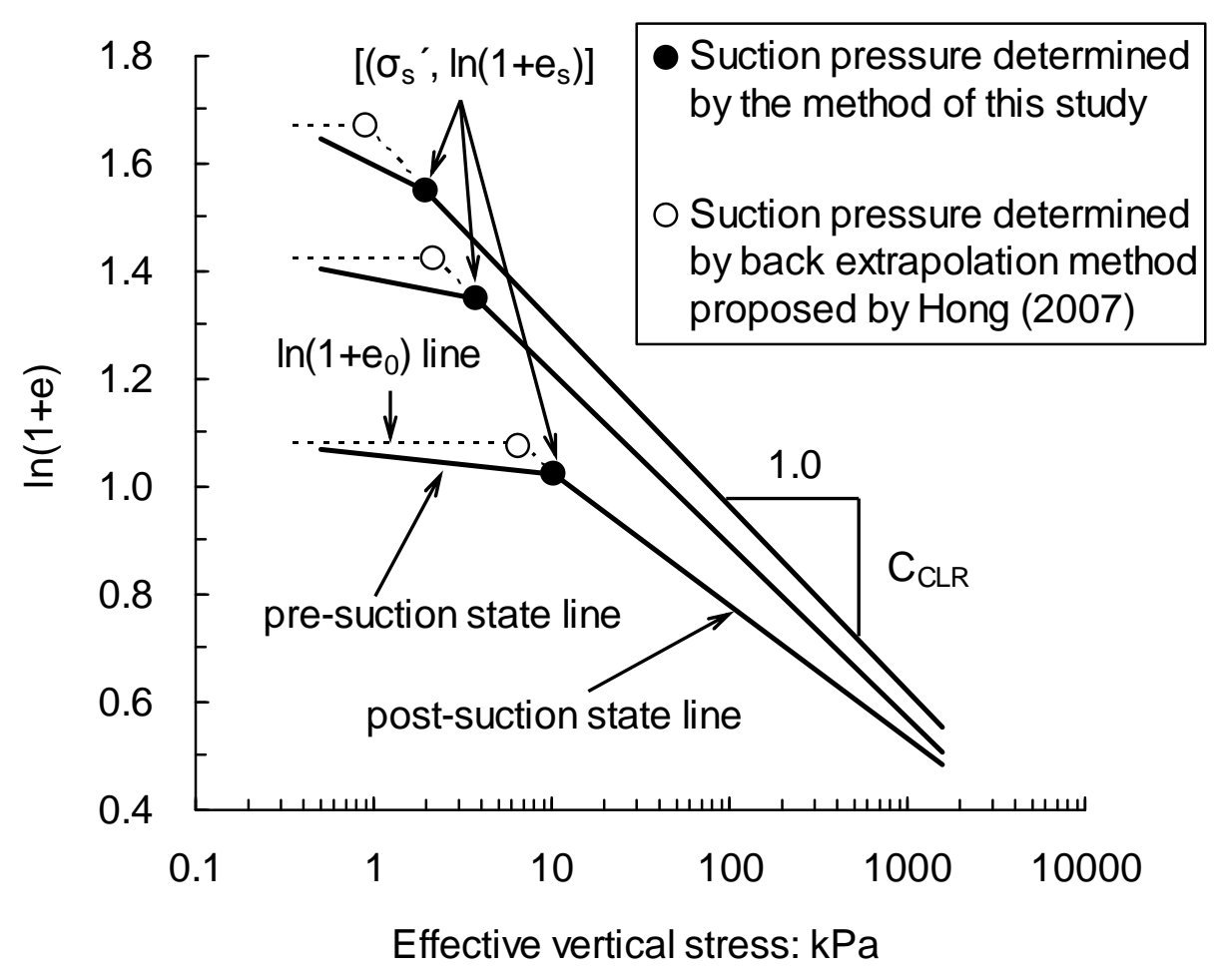

Fig. 9. Schematic plot of two methods in determining suction pressure 


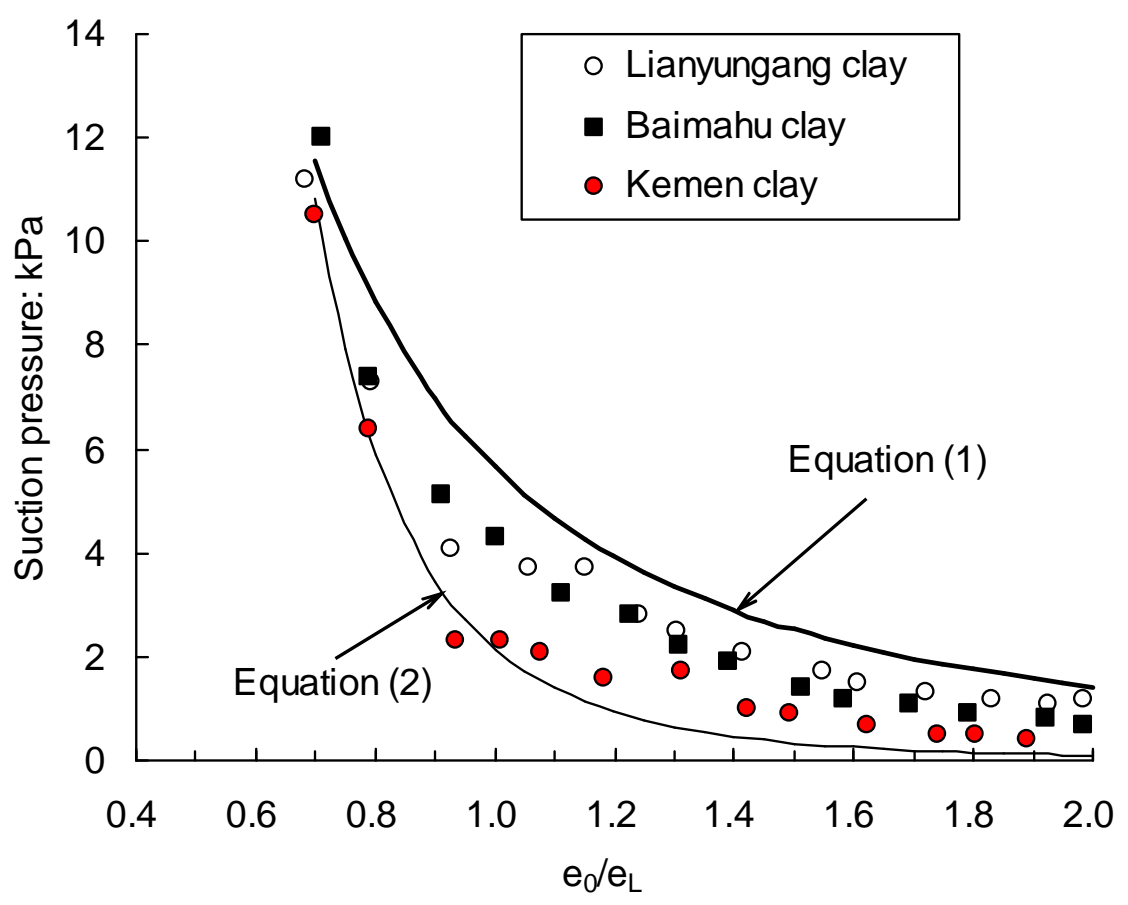

Fig. 10. Suction pressures determined by the extrapolating method of Hong (2007) based on the post-suction test data from this study 


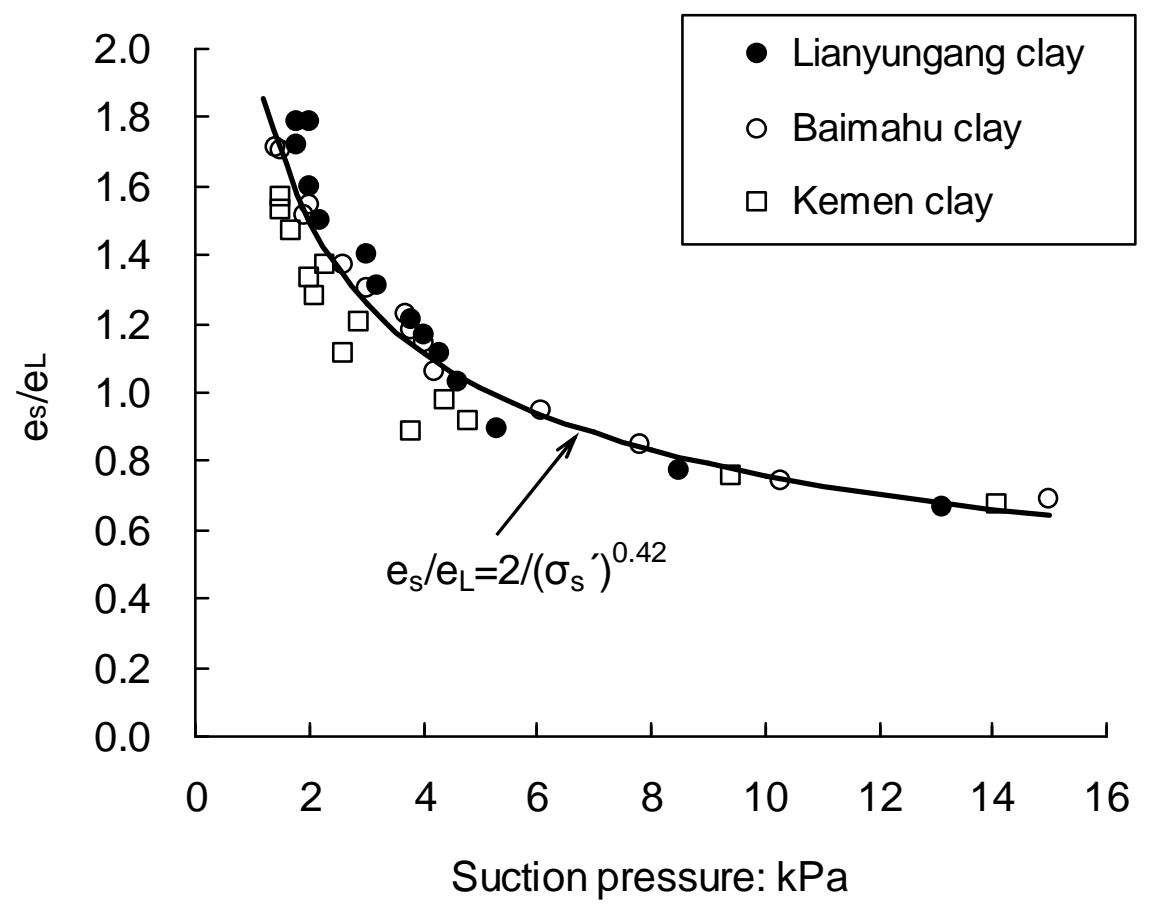

Fig. 11. Relationship between suction pressure and $\mathrm{e}_{\mathrm{S}} / \mathrm{e}_{\mathrm{L}}$ 


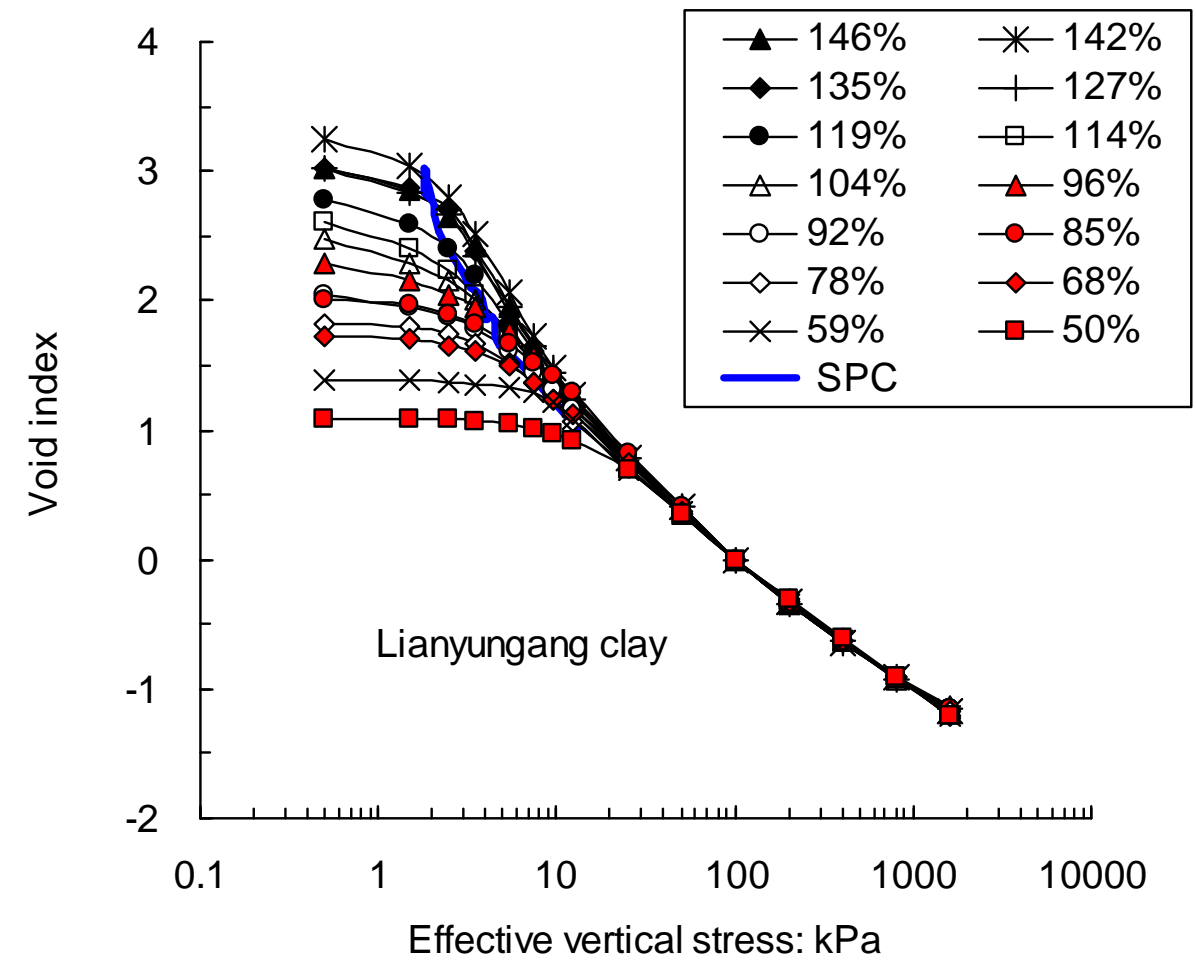

Fig. 12. Relationship of void index versus effective vertical stress for Lianyungang clay at different initial water contents 


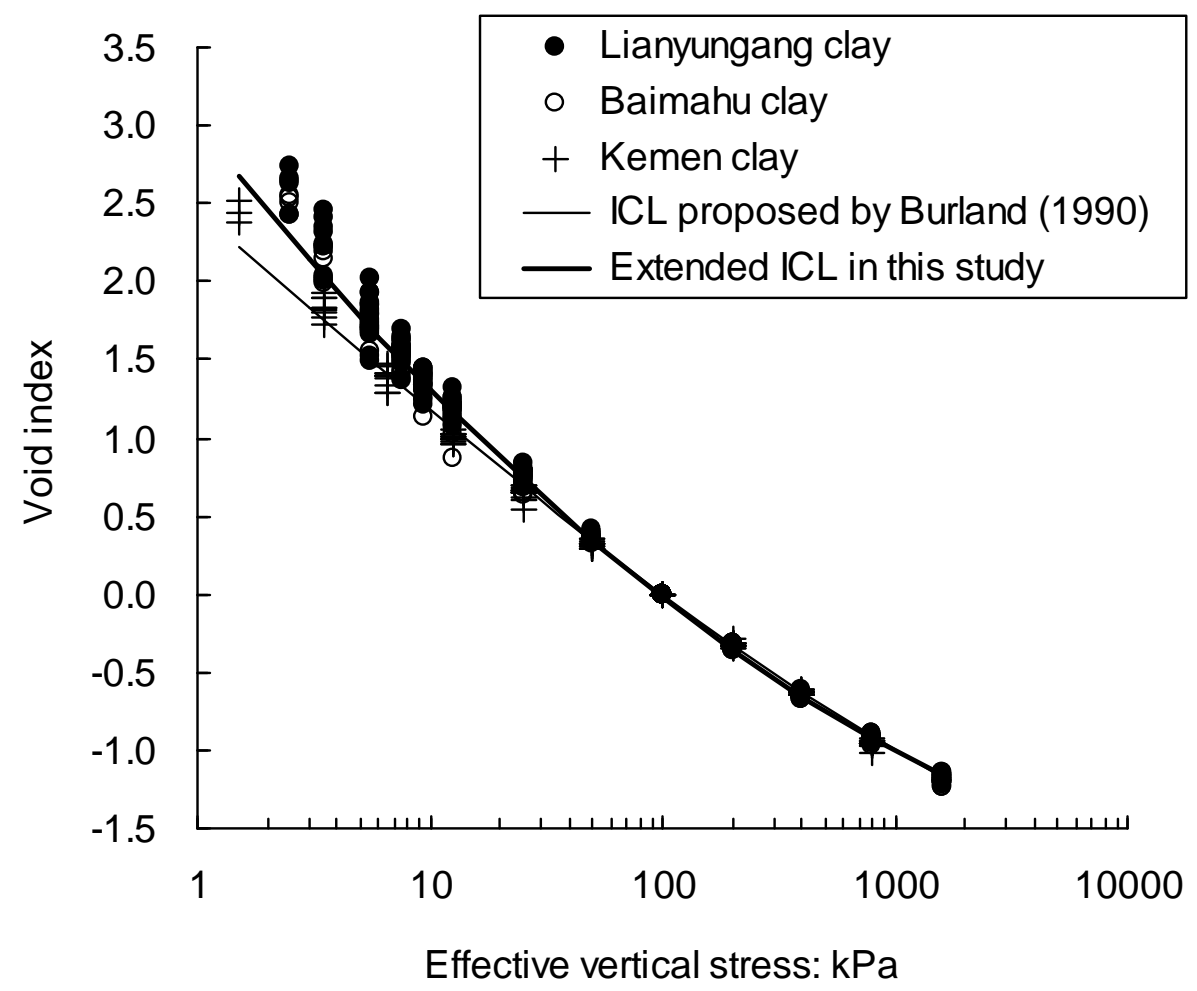

Fig. 13. Comparison of normalised compression curves with ICL 


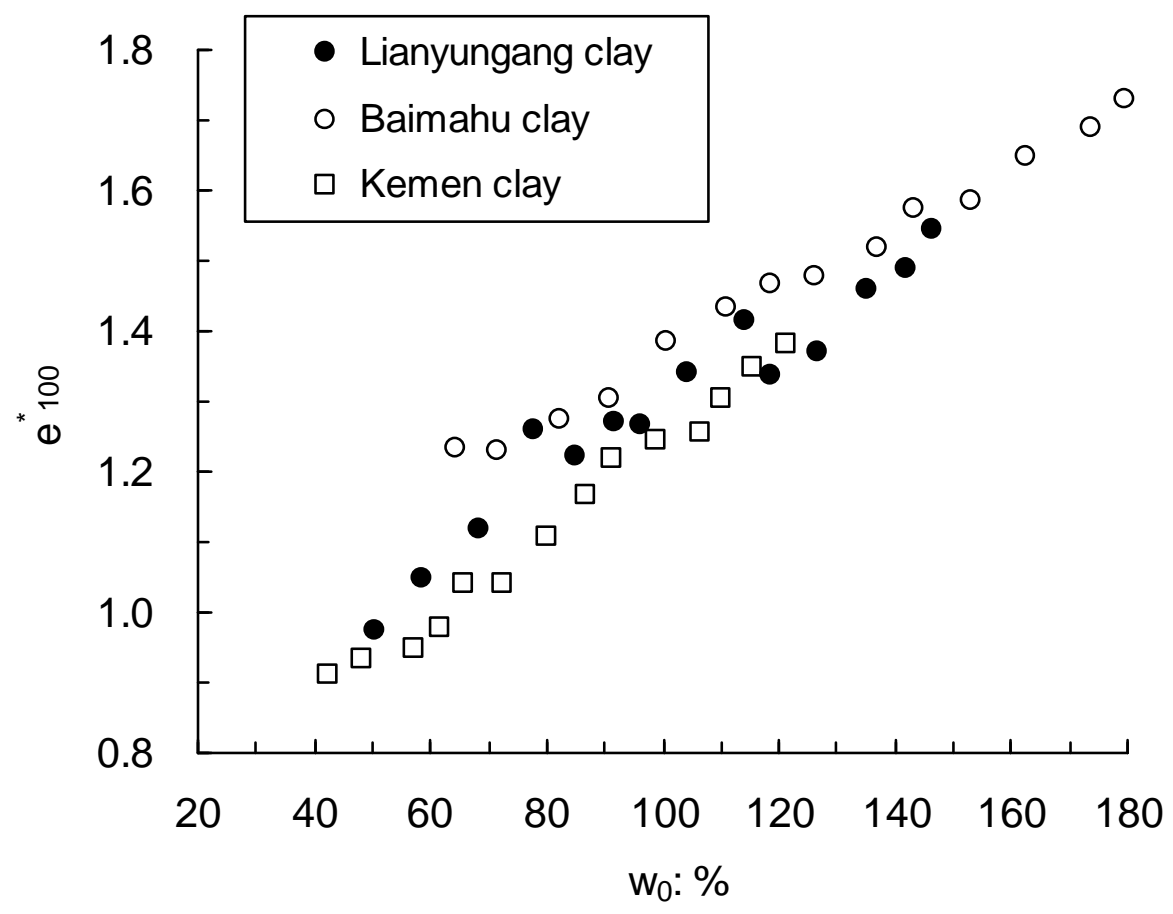

Fig. 14. Relationships of $e^{*} 100$ versus initial water content for different clays 


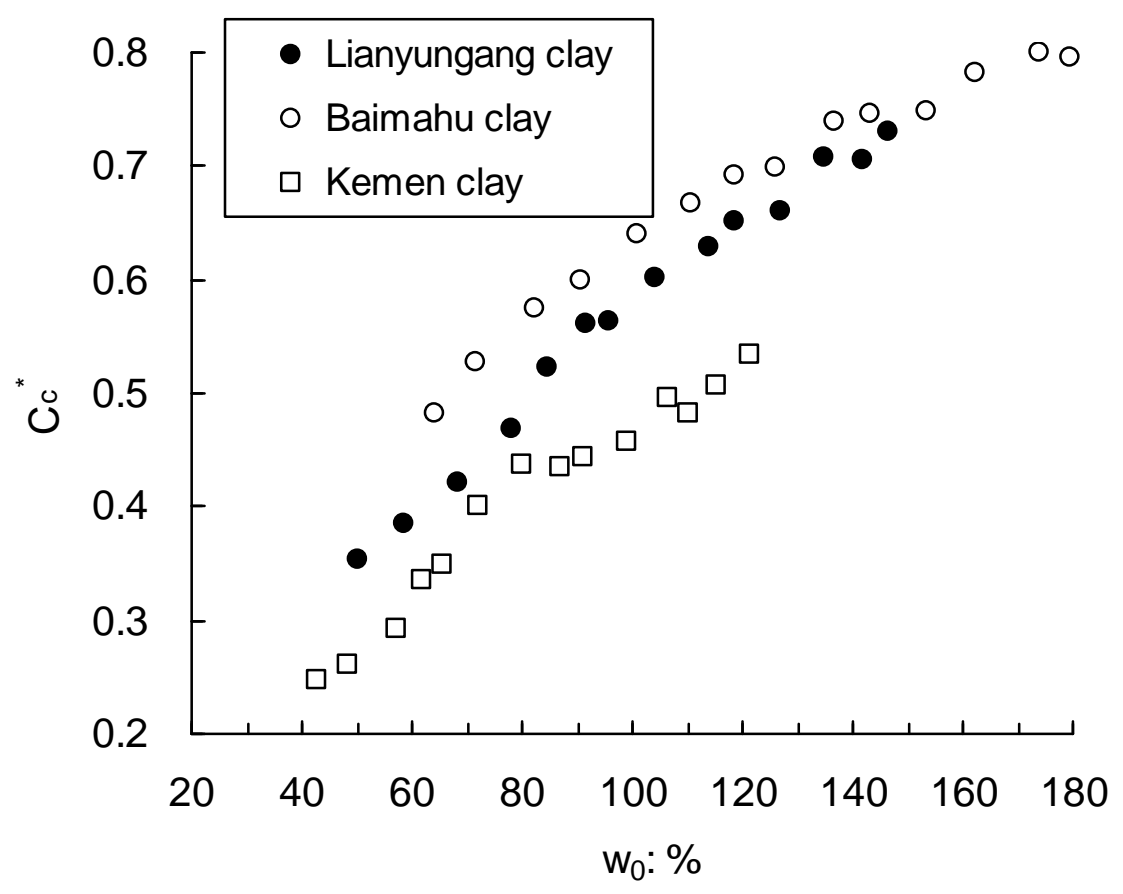

Fig. 15. Relationships of $C_{c}{ }^{*}$ versus initial water content for different clays 


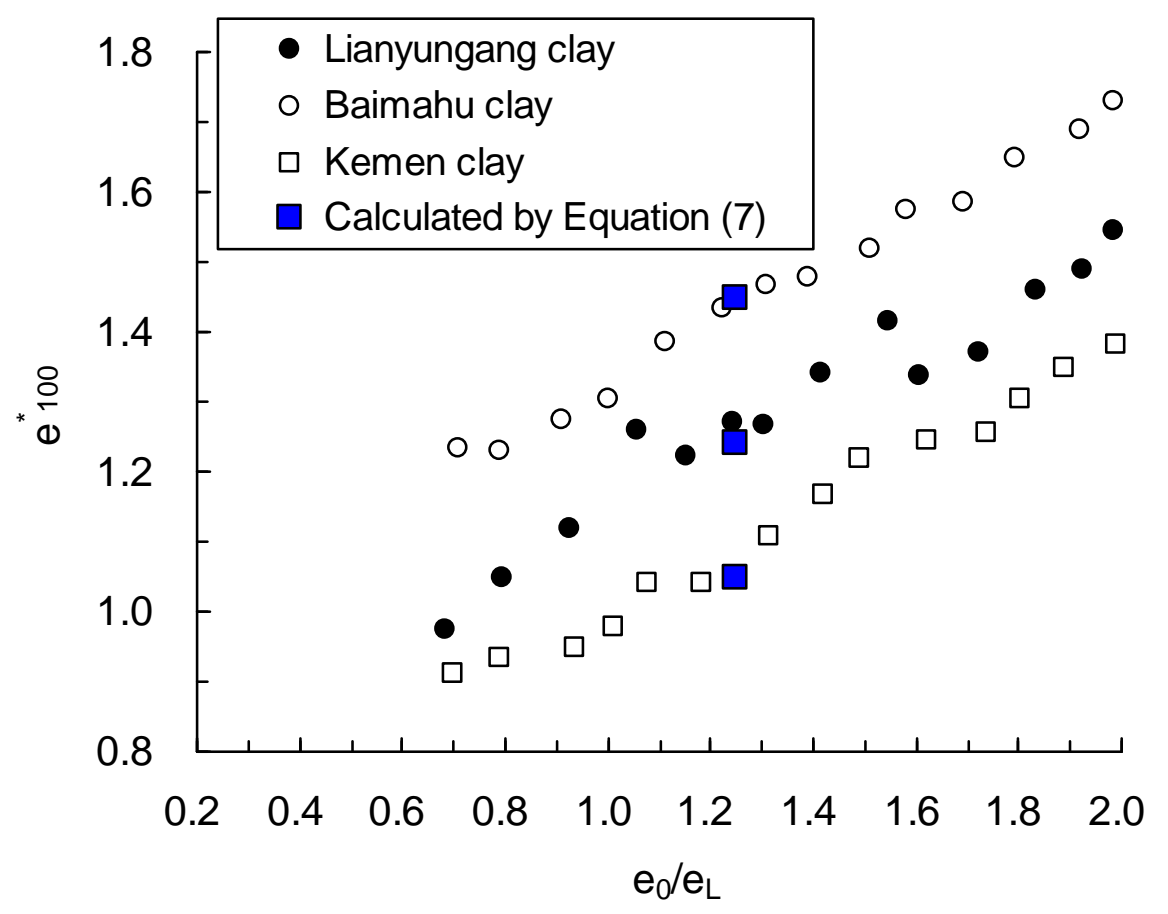

Fig. 16. Relationships of $e^{*} 100$ versus normalised initial void ratio 


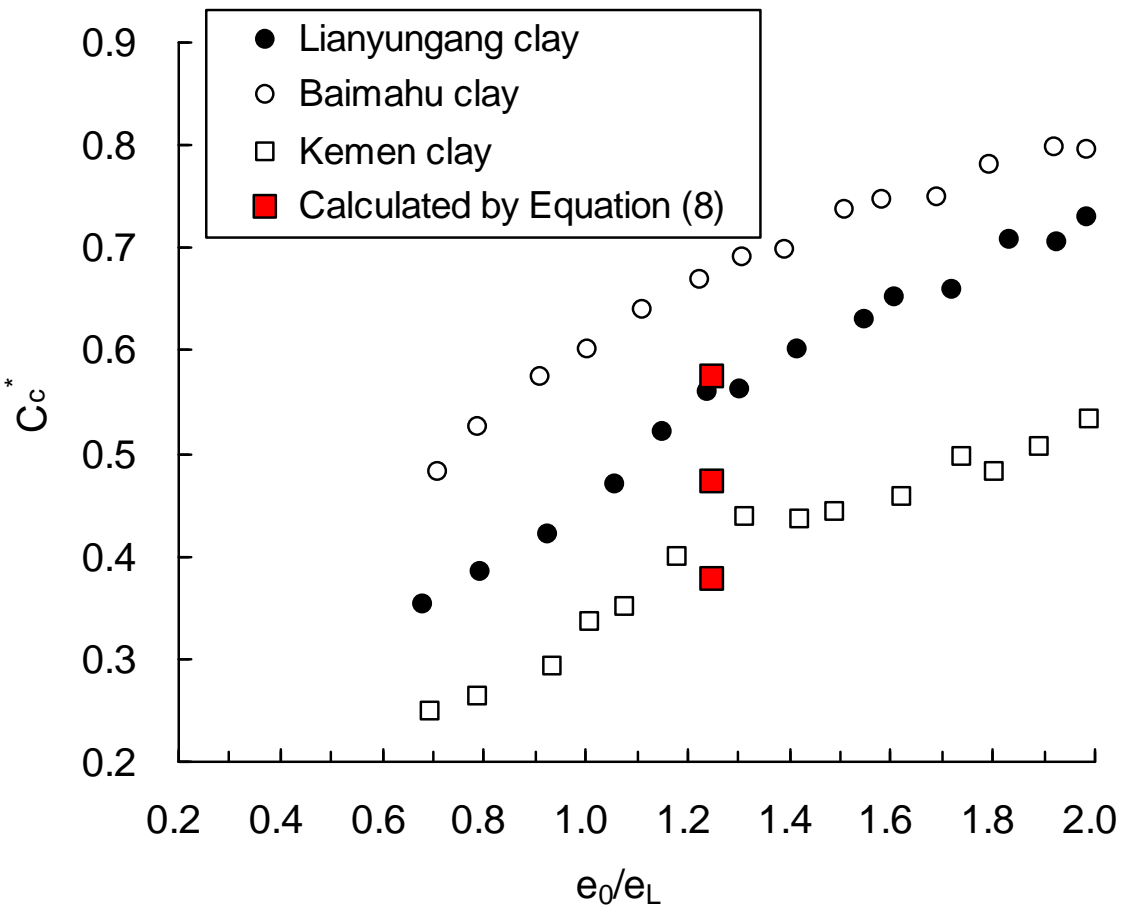

Fig. 17. Relationships of $C_{c}{ }^{*}$ versus normalised initial void ratio 